Article

\title{
Evaluation of Thermal Comfort in Traditional Houses in a Tropical Climate
}

\author{
Jalil Shaeri ${ }^{1, *}$, Mahmood Yaghoubi ${ }^{2}$ (), Ardalan Aflaki ${ }^{2}$ and Amin Habibi ${ }^{1(\mathbb{C}}$ \\ 1 Faculty of Arts and Architecture, Shiraz University, Shiraz 7188637911, Iran; a_habibi@shirazu.ac.ir \\ 2 School of Mechanical Engineering, Shiraz University, Shiraz 7193616548, Iran; yaghoubi@shirazu.ac.ir (M.Y.); \\ ar.aflaki@shirazu.ac.ir (A.A.) \\ * Correspondence: jalil.shaeri@shirazu.ac.ir; Tel.: +98-937-305-6253
}

Received: 18 July 2018; Accepted: 6 September 2018; Published: 9 September 2018

\begin{abstract}
A considerable amount of energy is being consumed for heating and cooling indoor environments in order to provide thermal comfort. For older buildings located in the southern parts of Iran, particularly in Bushehr, many climatic and passive design strategies are being used to provide indoor thermal comfort. This architecture and these elements have been developed in response to unfavorable weather conditions. The current study aimed to identify those passive elements and evaluate indoor thermal comfort in older houses. To achieve these objectives, passive elements in main houses located in the ancient urban structure were first identified. Then, a house in the coastal belt, Tabib's house, and another house inside the ancient urban structure, Nozari's house, were selected for the purpose of field measurement. The results revealed that the passive techniques used in these older houses significantly provide sufficient indoor thermal conditions. The mean measured predicted mean vote (PMV) of Tabib's rooms was 0.88 and the mean measured PMV of Nozari's rooms was 0.91 , which were in an acceptable range. The measured predicted percentage of dissatisfied of rooms in both houses were lower than $10 \%$. The main factor in creating indoor thermal comfort in these houses was the natural ventilation and its availability in the selected houses.
\end{abstract}

Keywords: thermal comfort; older architecture; hot-humid climate; wind velocity; Predicted Mean Vote (PMV); Predicted Percentage of Dissatisfied (PPD); natural ventilation

\section{Introduction}

Over $50 \%$ of people in the world live in cities and this amount will increase up to $80 \%$ by 2030 [1]. Considerable amounts of energy are used in the building sector to create indoor thermal comfort. Moreover, cities are the source of $70 \%$ of $\mathrm{CO}_{2}$ production in the world [2]. Greenhouse gas emissions, global warming, and high energy consumption in the residential sector have caused global concern with regard to the urban environment [3].

Meanwhile, comfortable indoor environments are due to the response of the original building architecture to seasonal variations in climate. In addition, older houses have kept occupants physiologically comfortable despite extreme climatic conditions. Climatic strategies that have been used in local and traditional buildings for many years were based on trial and error; these strategies provide valuable knowledge that has been neglected in modern architecture [4]. However, studies that were conducted on small scales have applied strategies of local and traditional architecture for modern buildings in multi-climates.

There are many passive design strategies with respect to the micro-climate, especially in the southern parts of Iran where the high temperature and relative humidity are dominant. In older houses in Bushehr, various passive elements have applied in order to create indoor thermal comfort. The urban structure of the southern part of Iran is different due to its hot and humid climate. Low latitudes, 
proximity to the sea, warm southwest winds, and hot-humid sea winds during autumn and winter [5] are amongst the factors creating this climatic condition. New studies indicated that there is a significant relationship between the concept of sustainability in cities and the concepts of density and compactness. This compact shape is not only remarkable in terms of structure but also in the development and design aspects of traditional architecture. This type of urban morphology in Bushehr ascertains comfortable indoor and outdoor thermal conditions [6].

Studies have shown that most of traditional buildings that have used passive systems for heating and cooling can provide better indoor thermal comfort in comparison with modern buildings. Moreover, these buildings are consuming less energy than modern buildings in the same micro-climate [7,8]. In a study in the hot-humid climate of Malaysia, the older houses in close relation with nature and culture of the region were studied to meet residents' comfort. Results of this study revealed that architectural elements like Transom Ventilation Panels (TVPs) and ornamental windows in all sides of the building could significantly improve indoor ventilation and air change rate [9]. In general, traditional houses in hot-humid areas were constructed to provide maximum thermal comfort with natural ventilation, and to specifically reduce moisture [10-12]. In order to use the wind in these regions, buildings have been constructed above the ground to allow the air coming in and out freely. This remarkably decreases the indoor air temperature in the residential buildings where the thermal condition of occupants is the main point of design [9]. In particular, air velocity reduces relative humidity, which can be an effective strategy in hot-humid climates $[13,14]$.

As an effective strategy, courtyards were also used in the older architecture to create suitable thermal conditions in residential buildings. A study by Ryu et al. [15] revealed that, due to cold weather between the yard and the backyard in traditional houses, the temperature difference could create a comfortable situation in the indoor environment. The difference between the temperatures in the designed courtyards created mild air velocity in the adjacent rooms. In a study of a traditional house in Oman, the sea breeze was used to moderate high relative humidity inside the house by means of natural ventilation [16]. In general, the traditional houses in close proximity to coastal areas have been designed sophisticatedly in order to lead wind directly and indirectly to buildings [17]. In order to sufficiently apply wind in these buildings and use maximum sunlight in the cold seasons, buildings are oriented in the east-west direction [10]. Shading devices are installed horizontally and vertically on top of windows and apertures, especially in the south direction to achieve heat avoidance techniques. By controlling intensive solar radiation through the application of shadings in balconies and increasing the cross ventilation through the shaded windows, an acceptable indoor thermal condition is created in older homes $[10,13,18]$.

Light colors on the surfaces at the outside and local materials with low thermal conductivity such as wood, bamboo or palm tree trunk, stone, mud, and lime were used in buildings to reduce the transformation of heat from outside to the inside [19]. The central courtyard in this region was small to receive less sunlight during the day. The heat was easily transferred to the surrounded environment at the night time from the external surfaces of the courtyard and roof. This helped the building to act as a heat sink and remove the heat quickly [13].

Various studies have applied passive design elements in order to promote comfort conditions inside the buildings. Fernandes studied the climate strategies in older architecture in the northern and the southern parts of Portugal [20]. Results of this study showed that older houses could provide good thermal performance by passive strategies and occupants felt comfortable conditions most of the time. However, it was noted that occupants should use simple heating systems during winter to have acceptable comfort. In another study, thermal conditions of an older building were evaluated in Evora, Portugal; the results revealed that passive cooling techniques can improve indoor thermal comfort, especially in hot seasons. According to the outcomes, the difference between indoor temperatures and the maximum outdoor temperatures in the courtyard and the city center were $7{ }^{\circ} \mathrm{C}$ and $16^{\circ} \mathrm{C}$, respectively. These older strategies offer potential for decreasing energy consumption in modern buildings [21]. Further studies in this field have indicated their effectiveness at keeping indoor 
temperature in an acceptable range. In a study by Fernandes et al. [22], thermal performance of older buildings was examined in Egypt and Portugal. The results showed that there is a correlation between the thermal performance of older buildings and human comfort perception in two different locations in the Mediterranean climate. The study showed that common passive techniques in both case studies were different due to their locations. However, traditional passive strategies were used in both countries to achieve acceptable thermal conditions and reduce mechanical systems load.

Kubota and Toe [23] investigated how passive cooling strategies in older houses can be used in modern houses to reduce energy consumption in Malaysia. They used experimental measurements in two traditional Malay houses and two traditional masonry Chinese shophouses. They measured indoor thermal conditions and the effectiveness of passive cooling techniques in the selected case studies. The results revealed that the indoor air temperature of the rooms adjacent to the courtyards were $5-6{ }^{\circ} \mathrm{C}$ lower than the outdoor temperature during daytime. Based on the results, they introduced an adaptive thermal comfort equation for hot-humid climates. Moreover, the study identified passive strategies in older houses, including night ventilation, roof and ceiling insulation, window and wall shading, and courtyards.

Al-Rashed et al. [24] investigated the role of Mushrabiyah, courtyard and adobe construction, for Dhahran, Guriat, Riyadh, Jeddah, and Khamis Mushait in Saudi Arabia. They designed a base, and then created the base house with electricity value, and the houses were adjusted with these passive strategies and materials. Results revealed that courtyards were not useful from the aspect of energy saving. Using Mushrabiyah can reduce energy consumption by 3 to $4 \%$, and adobe can reduce energy consumption by 6 to $19 \%$.

The importance of the courtyard has been identified in a Chinese house in a hot-humid climate, where this element was designed in the form of a pure courtyard and patio with semi-open spaces in order to create indoor thermal comfort [25]. Different types of courtyards in older Chinese houses in hot and humid climates perform different functions to promote indoor thermal comfort [26]. In a study in Iran, it was proved that Shavadan spaces in traditional houses in the hot-humid region can create thermal comfort and reduce cooling and heating loads [27]. Studies of passive strategies in an older house in India also indicated the relationship between traditional architectural features and thermal comfort conditions $[28,29]$. In addition, replacing rubble stone masonry with burnt clay brick masonry and stabilized soil block masonry increased the embodied energy of the dwelling by 9.7 times $(870 \%)$ and 2.8 times (182\%), respectively [29]. Applying traditional materials, such as adobe, remains the best option in humid hot-climates [30].

A literature review in the field of older architecture indicates that such creativity, if applied in modern buildings, will significantly promote thermal comfort and energy savings. In the older architecture of Bushehr, Iran, innovative designs including internal and external Shenashir, terraces surrounding rooms, and courtyard with rooms surrounding them, have been used with the purpose of reducing humidity and temperature. These innovative elements could significantly promote indoor thermal conditions, especially through the hot season. This study aims to introduce the these elements in older architecture through evaluating these effective elements. The results can contribute to the world of knowledge and offer valuable strategies and techniques for modifying current constructions and utilizing new developments. Based on these aspects, the objectives of this study were: (1) identifying passive strategies in the traditional context and houses of Bushehr, Iran; and (2) evaluation and comparison of indoor thermal comfort in two older houses in Bushehr (Tabib and Nozari houses), as shown in Figure 1. 


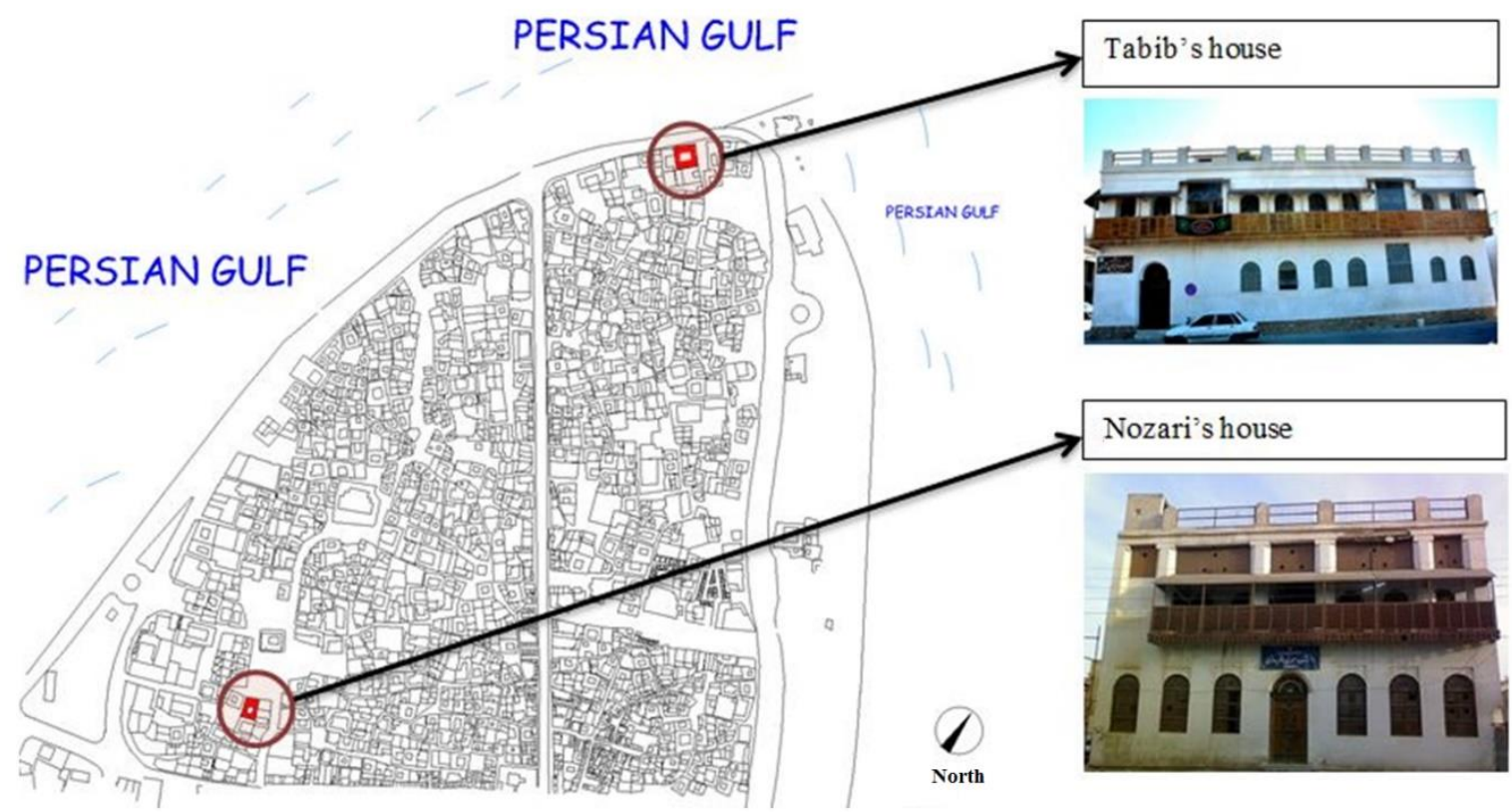

Figure 1. Location of Tabib's and Nozari's houses in Bushehr, Iran representing traditional architecture.

\section{Climate}

Bushehr lies at $28.96^{\circ} \mathrm{N}$ and $52.83^{\circ} \mathrm{E}$. It is a port city located next to the Persian Gulf. Based on Figure 2, the climate of Bushehr is hot-humid. The monthly weather conditions of the city are provided in Table 1. Based on Table 1, June, July, August, and September are the warmest months during a year.

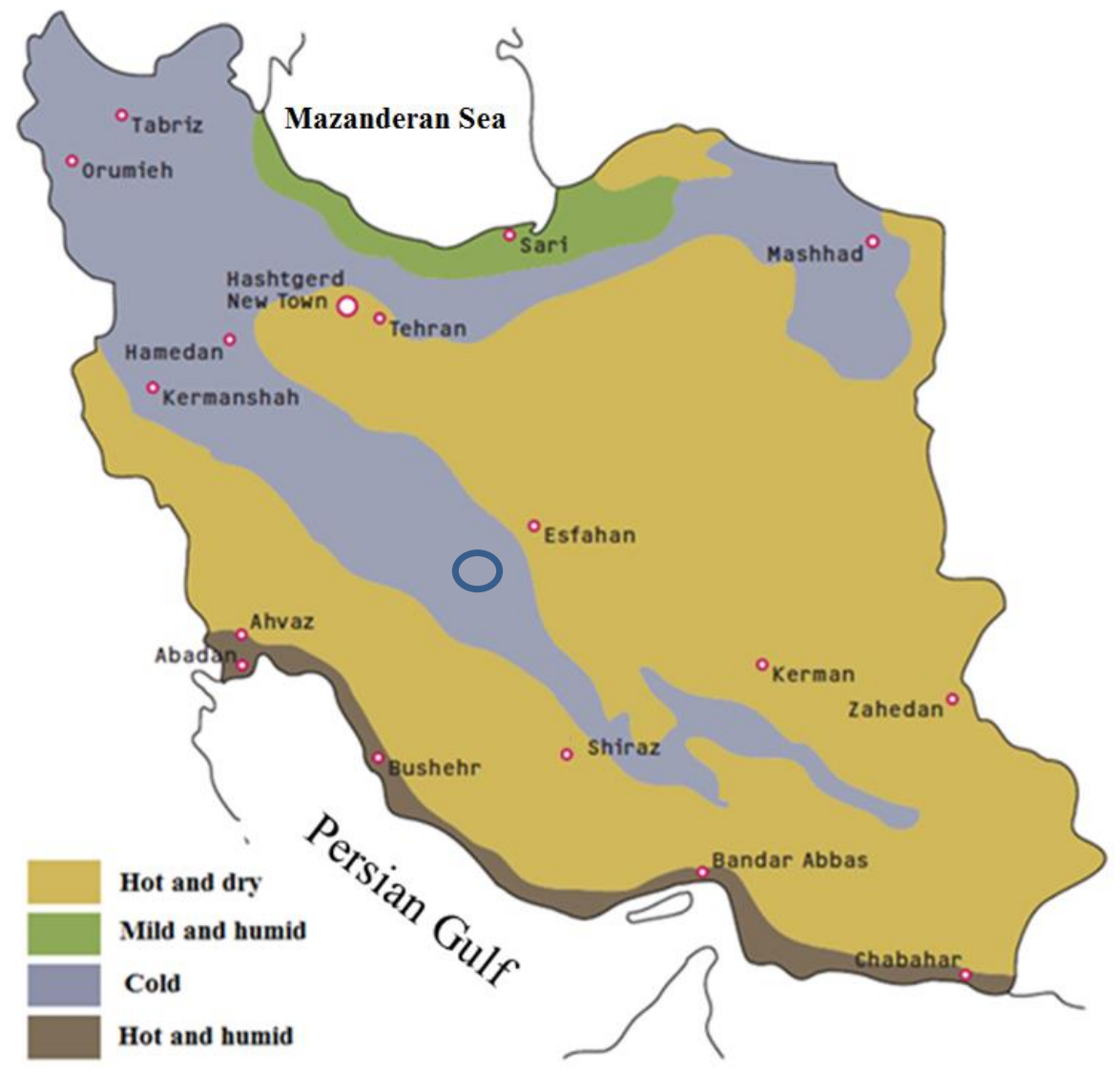

Figure 2. Climate divisions of Iran [31]. 
Table 1. Monthly average of weather condition in Bushehr, Iran (2000-2016) cited from Iran Meteorological Organization.

\begin{tabular}{|c|c|c|c|c|c|c|c|c|c|}
\hline Month & $\begin{array}{c}\text { Average } \\
\text { Temperature } \\
\left({ }^{\circ} \mathrm{C}\right)\end{array}$ & $\begin{array}{c}\text { Min } \\
\text { Temperature } \\
\left({ }^{\circ} \mathrm{C}\right)\end{array}$ & $\begin{array}{c}\text { Max } \\
\text { Temperature } \\
\left({ }^{\circ} \mathrm{C}\right)\end{array}$ & $\begin{array}{c}\text { Average Relative } \\
\text { Humidity (\%) }\end{array}$ & $\begin{array}{l}\text { Min Relative } \\
\text { Humidity (\%) }\end{array}$ & $\begin{array}{l}\text { Max Relative } \\
\text { Humidity (\%) }\end{array}$ & $\begin{array}{l}\text { Average Wind } \\
\text { Speed }(\mathrm{m} / \mathrm{s})\end{array}$ & $\begin{array}{l}\text { Min Wind } \\
\text { Speed }(\mathrm{m} / \mathrm{s})\end{array}$ & $\begin{array}{l}\text { Max Wind } \\
\text { Speed }(\mathrm{m} / \mathrm{s})\end{array}$ \\
\hline January & 14.9 & 8 & 22.2 & 74 & 44 & 100 & 4.0 & 0.1 & 12.7 \\
\hline February & 16.5 & 10.6 & 23.9 & 72 & 44 & 100 & 4.5 & 0.1 & 12.8 \\
\hline April & 24.2 & 17.4 & 34 & 66 & 43 & 97 & 4.3 & 0.2 & 13.2 \\
\hline May & 29.3 & 22.9 & 36.5 & 59 & 38 & 98 & 4.5 & 0.1 & 12.9 \\
\hline June & 31.0 & 26.7 & 37.8 & 65 & 42 & 92 & 4.1 & 0.2 & 12.9 \\
\hline July & 33.1 & 27.7 & 38.8 & 67 & 42 & 96 & 3.9 & 0.1 & 12.5 \\
\hline October & 28.4 & 22 & 35.2 & 68 & 38 & 99 & 3.2 & 0.1 & 11.2 \\
\hline November & 22.0 & 13 & 31.6 & 65 & 36 & 98 & 3.8 & 0.1 & 12.3 \\
\hline December & 17.1 & 9.5 & 26.5 & 75 & 45 & 100 & 3.7 & 0.1 & 10.9 \\
\hline
\end{tabular}

In Figure 3, the local wind directions for Bushehr are illustrated. According to the figure, the dominant wind direction throughout the year is north and northwest, and the average wind speed is $3.5 \mathrm{~m} / \mathrm{s}$. The wind from the northwest direction with the angle of $320^{\circ}$ is blown to the north direction and has a relative humidity of $50 \%$ and a temperature of $22{ }^{\circ} \mathrm{C}$, which is very desirable. In addition, the wind with an angle of $300^{\circ}$ is blown to the north direction and is the most prevalent wind throughout the year, with a mean relative humidity of $50 \%$ and an average temperature of $31^{\circ} \mathrm{C}$.

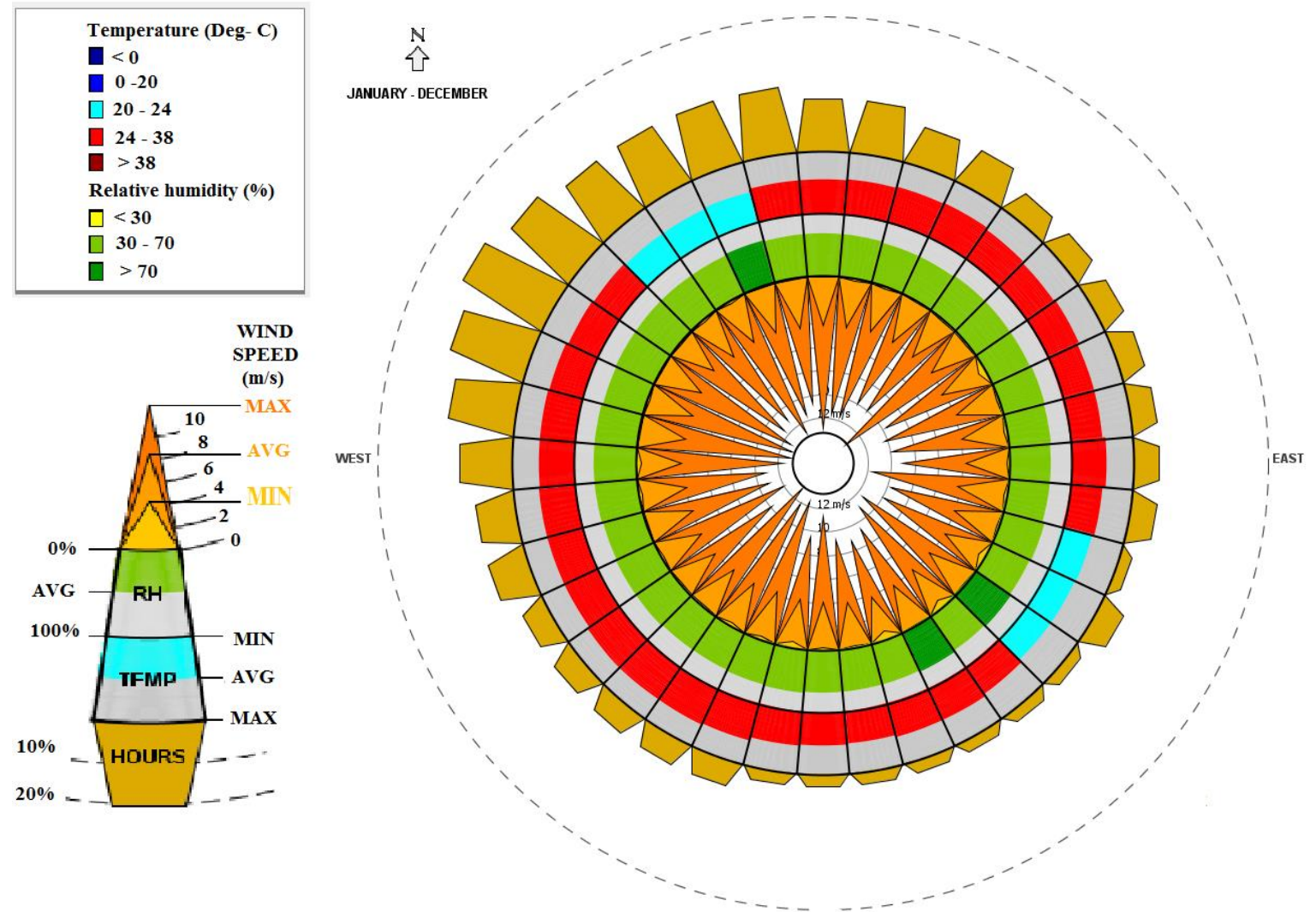

Figure 3. Daily average of wind velocity variation and direction during a year at Bushehr (Climate Consultant software).

\section{Traditional Context of Bushehr}

The traditional context of Bushehr in terms of location has the possibilities for creating calm conditions. In this context, the greatest potential to create comfort is the way in which wind blows through streets and buildings. The whole urban compactness is shown in Figure 4a, with narrow streets and alleys that are higher than their width (the ratio of width to height reaches 1-6) [32]. This in turn creates permanent shade, which considerably impacts reducing ambient temperature. 
Also, an increase in the length of the building is effective with respect to increasing the speed of wind within the pathways, as is illustrated in Figure $4 \mathrm{~b}$.

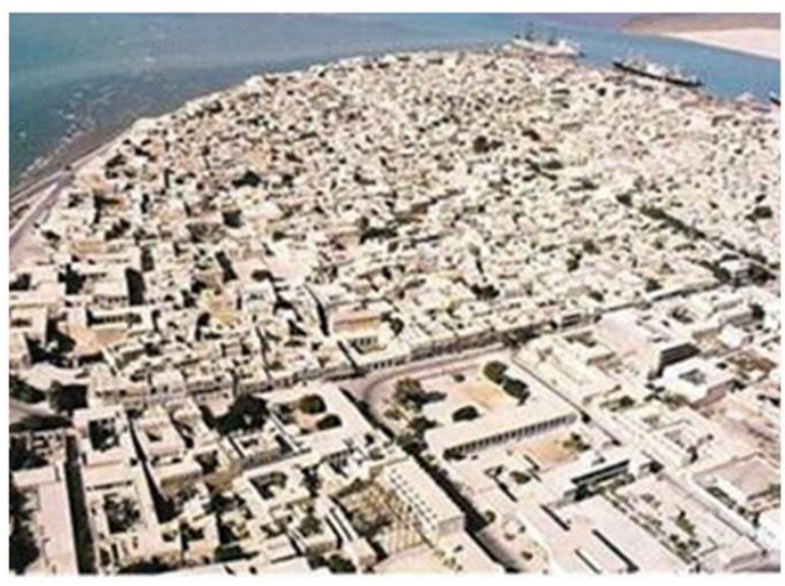

(a) Traditional compact texture of Bushehr

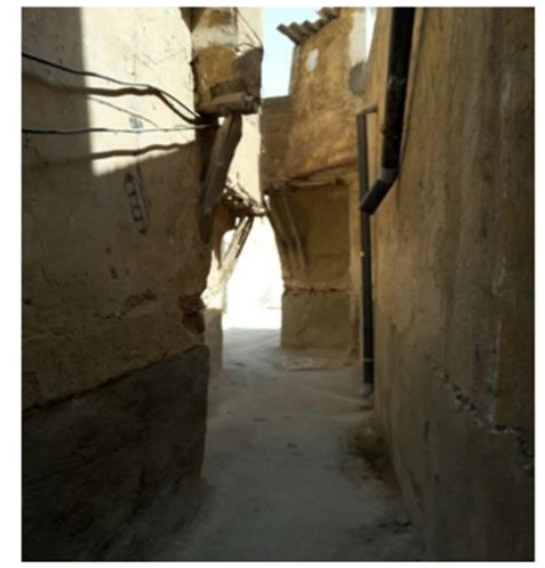

(b) Narrow alleys in the traditional context of Bushehr

Figure 4. Texture and narrow alleys in the traditional context of Bushehr.

Meanwhile, in order to attain thermal comfort, porches and Shenashirs, which connect the indoor environment to the alleys and streets in a neighborhood play a crucial role [6]. Figure 5 indicates how these elements act as effective shading in order to block solar radiation.
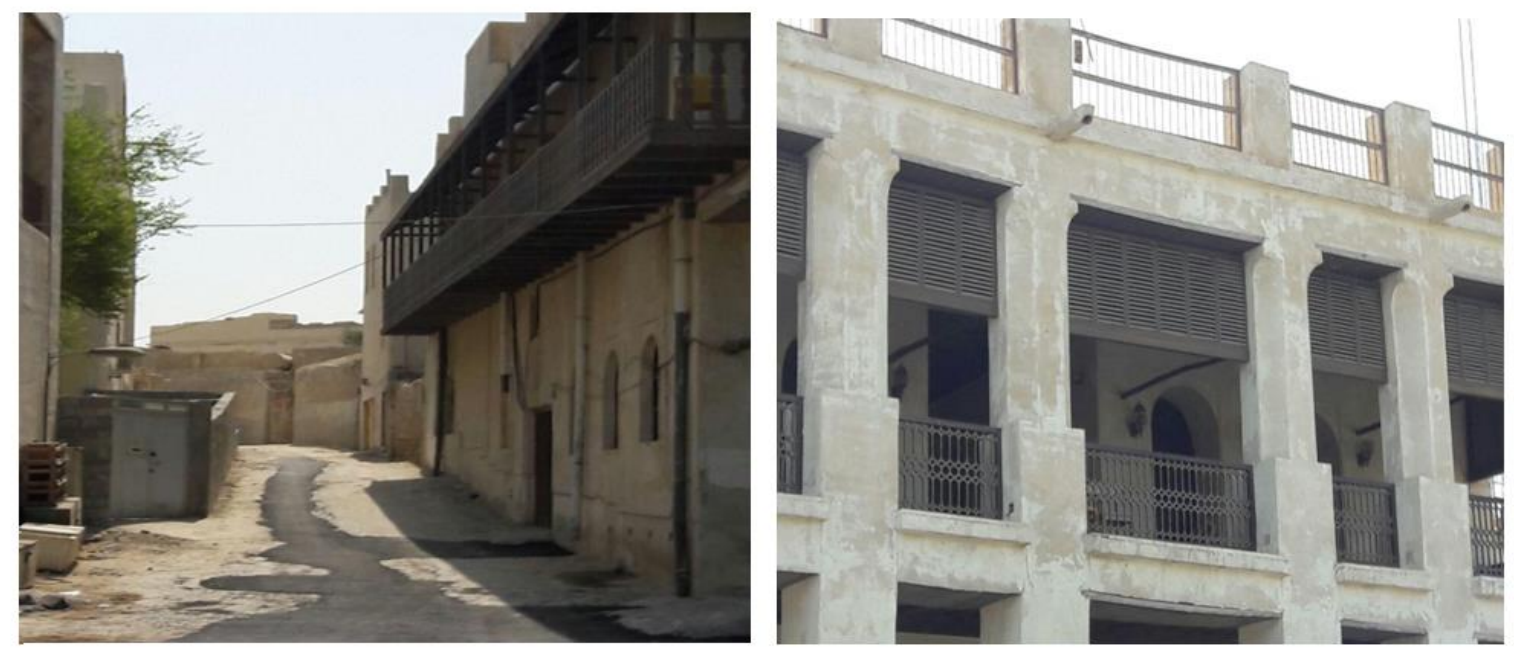

Figure 5. Using semi-open space for shading in a traditional building in Bushehr. (left) Using Shenashir in the outer facade for the purpose of shading, (right) Using a porch for the purpose of shading.

The space and structure cause air pressure differences in the atmosphere. This causes suitable wind conditions in the old urban structure of Bushehr [6,33]. The color of the building is light, so it reflects sunlight as shown in Figure 6. This strategy reduces the total amount of heat absorbed by the external walls. Moreover, public spaces are shaped sophisticatedly to circulate wind flow within the old neighborhood where most of the windows have been positioned at the external façade of the buildings to receive acceptable wind from the outside. Openings are formed at different levels in various forms. As shown in Figure 6, visual diversity and climate concern were two important factors in the design of windows on the external façade. 


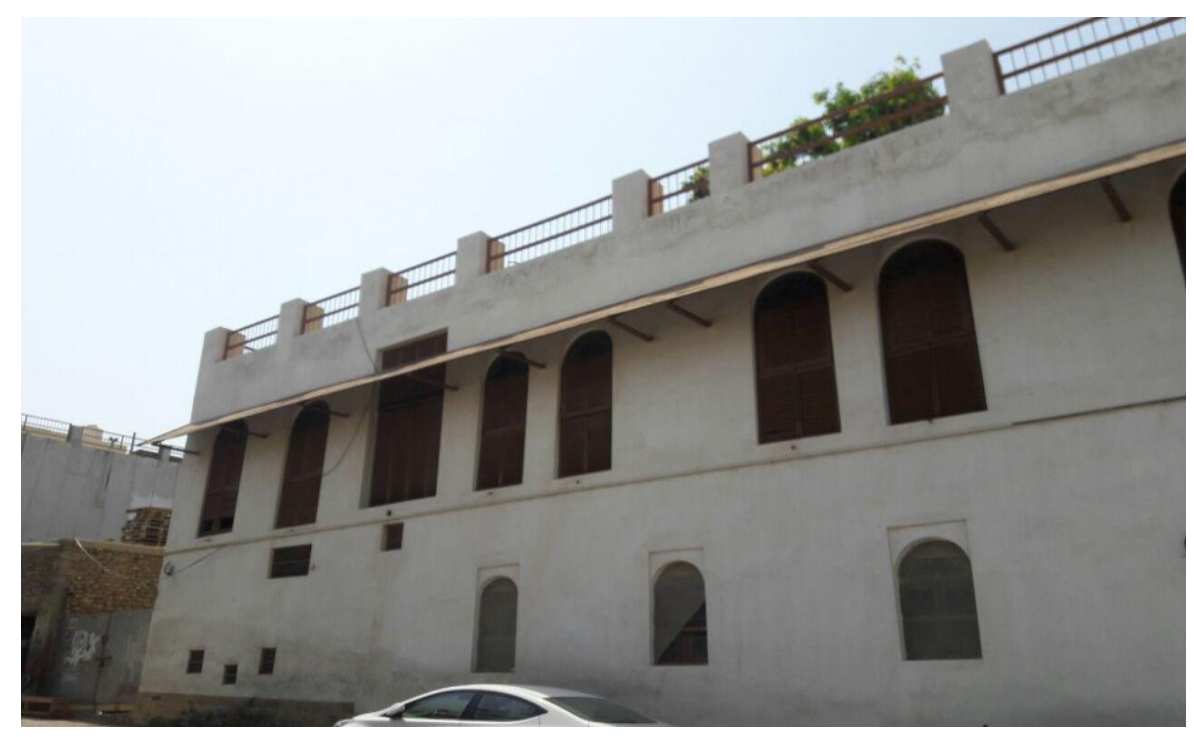

Figure 6. Using light color and outer openings.

Due to the porous stones that are used as the local building material, drying walls causes the interior to absorb moisture. In fact, by creating wind in the streets, some of the moisture through the wall surface will be directed outward. Therefore, one of the most important climatic factors that affect urban ventilation conditions is the regional wind, which is the best way to deal with harsh climatic conditions $[34,35]$. Using shadings and air flow are the two most important factors in determining the urban fabric and creating human comfort [36].

\section{Passive Design Solutions in Tabib's and Nozari's Houses}

Buildings were built in the east-west orientation in order to create comfort conditions in the living space. Based on the investigation in the current study, temperature and humidity, which are controlled by the architectural elements, can be highlighted in the following cases:

(1) Yard: Yards have a close relation with the wind and is assumed to be a place for providing wind circulation. The central courtyard reduces air temperature at the internal spaces by replacing fresh and cool air from the outside. The courtyard, as a passive design strategy, creates indoor air velocity to the adjacent rooms by means of stack and cross ventilation.

(2) Shenashir: This is a half-closed space located in the front of the closed space and protects the closed backspace from direct sunlight. On the other hand, due to the building's shadow on the outer surface, the temperature of the chamber reduces. External and internal Shenashir are shown in Table 2 and Figure 7.

(3) Openings: They play an important role in the hot-humid climate. The location of openings in a room is mostly related to the wind direction. In the architectural design of openings, it is important to determine the orientation of the openings in the building to provide appropriate light and air flow. In most of the cases, openings are exposed to the outside and orientated to the north and south.

(4) Terrace: This is a non-enclosed space covered and located on each individual level of the building. A terrace is surrounded by and covered with wooden blinds and sun straw. Terraces of the houses are half open space that are exposed to air and are cooler than other parts of the building. In addition, terraces bring favorable winds into the spaces of the building itself. Terraces are shown in the plans in Table 2 and Figure 8.

(5) Rooms: They are usually surrounded by the yard at different sides. The ratio of height to the width is not too large, normally $1: 2$ or 1:3. These ratios offer better ventilation in the yards as well as rooms in close proximity to the yard. The height of a room causes warm air to moved upward 
and reduces the room air temperature. In addition, building height is an element that provides wind pressure at the external surface building. As a result, a building can be naturally ventilated by the difference in pressure.

(6) Single-layer rooms: Rooms have two effective side: yard and surrounding streets sides. They have openings on both sides to provide wind circulation. Because of the importance of airflow, each space should have a window for air pressure in the suction area as well as another outgoing path. Thus, it is better to have outdoor space with two fronts in relation to the airflow. In general, natural ventilation in the buildings has three passive effects that are outlined in Figure 9.

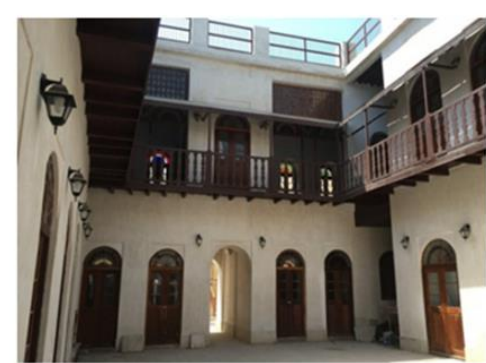

(a) Internal Shenashir in nozari's house

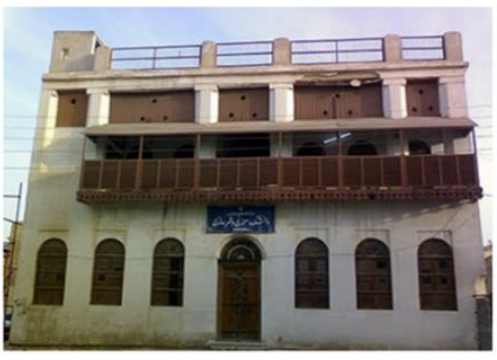

(b) External Shenashir in Nozari's house

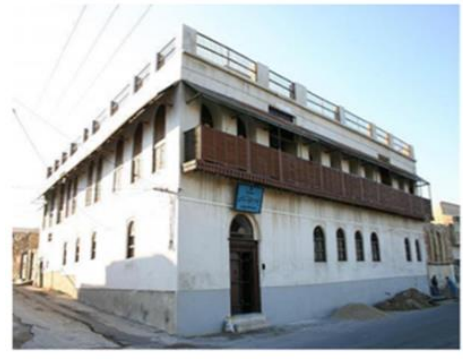

(c) External Shenashir in Tabib's house

Figure 7. External and internal Shenashir in Tabib's and Nozari's houses.

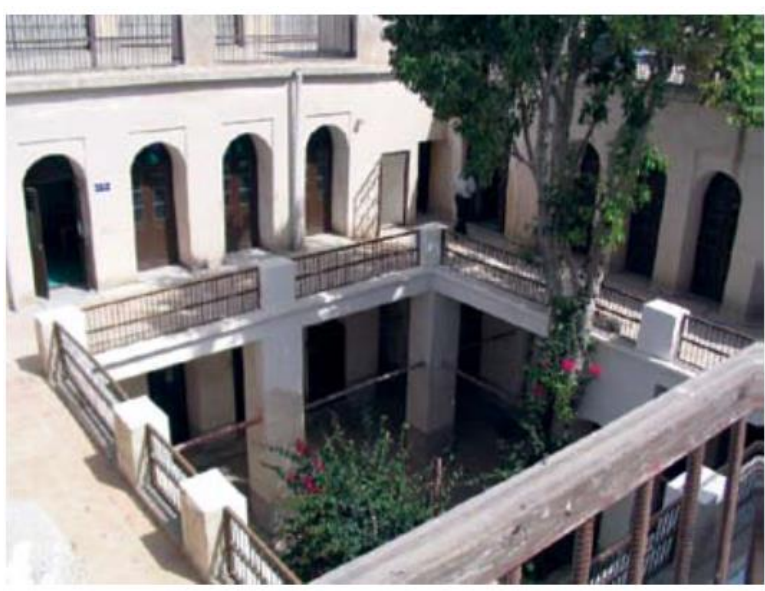

(a) Terrace in Tabib's house.

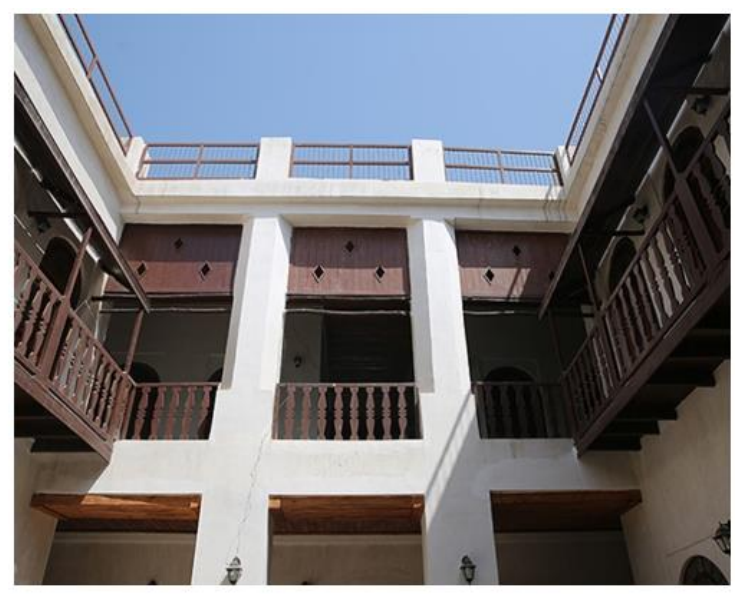

(b) Terrace in Nozari's house.

Figure 8. Terrace in Tabib's and Nozari's houses for shading.

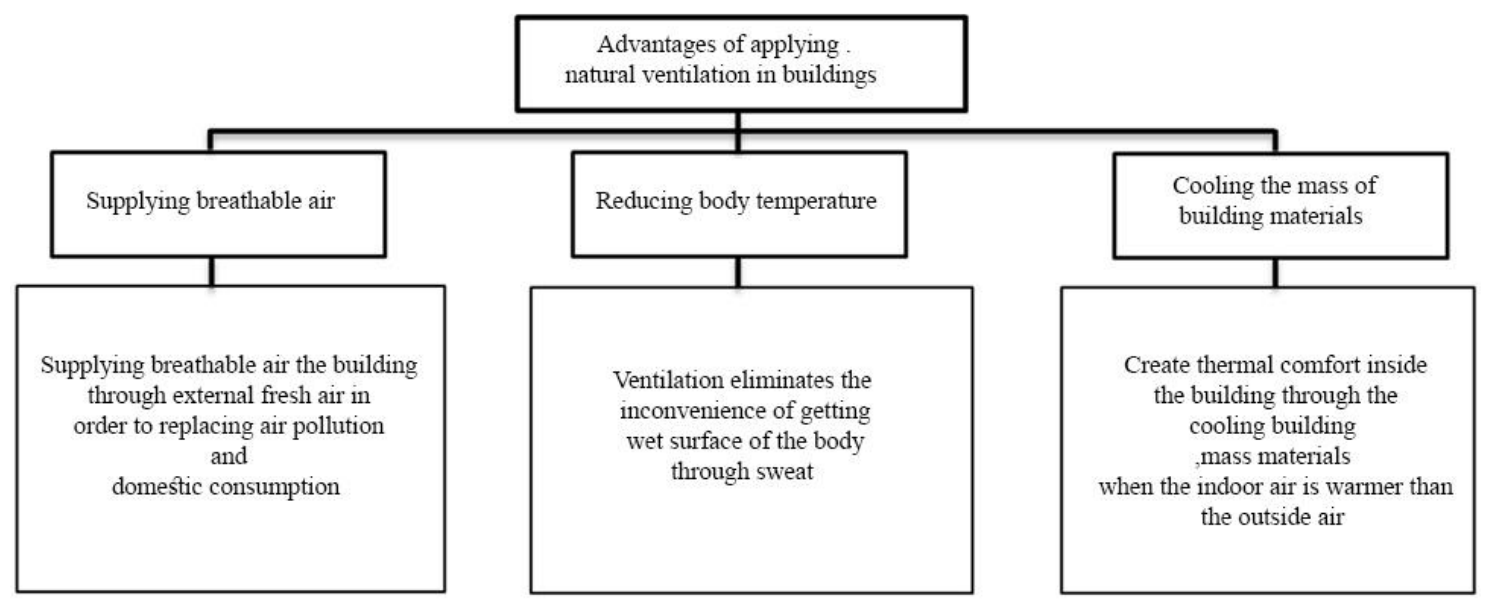

Figure 9. Performance of natural ventilation in traditional buildings. 
Materials used in the buildings of Bushehr are different. They include local rock, local plaster (lime), wood (of mangrove), wooden plate, rattan, cast iron, glass, and mortar shell. The materials are selected according to ease of access to mines and adaptation to climatic conditions.

(1) Stone: Coral reef rock with limestone is one of the basic materials in Bushehr. The stone is used in the foundation, walls, and in building facade because it has high resistance to moisture. These rocks are porous with very good thermal and acoustic insulation properties.

(2) Mud mortar and plaster: Clay is beaten and mixed with hydrated lime and water and used as mortar for building structures in building foundations and walls. The mortar is used in places where moisture and water penetration directly affects the building.

(3) Wood: Materials with low thermal conductivity like wood are used in hot-humid climates. The main problem is overheating and storing heat in this climate, which should not be transferred inside the building. For this reason, the best types of material is wood roofing. These materials can be used both for windows and doors. Wood releases heat slowly and transfers the gained heat smoothly. Thus, the wood surface remains relatively cool in the evening.

\section{Methodology}

\subsection{Sensors and Data Logger}

Previous research demonstrated the successful results of empirical experiments as a technique for simulating real conditions in residential buildings. Results from such experiments are more valuable and reliable than other methods and theoretical calculations. Therefore, in this research, a full-scale field measurement of two residential units in Bushehr, with the purpose of evaluating indoor thermal conditions, were studied. For this purpose, air temperature and relative humidity were measured with a MIC-98583 (Taipei, Taiwan) sensor with $\pm 0.6{ }^{\circ} \mathrm{C}$ accuracy in temperature and $\pm 3 \%$ accuracy in relative humidity. Wind speed was measured with an AVM-305 (Taipei, Taiwan) sensor with $\pm 0.2 \mathrm{~m} / \mathrm{s}$ accuracy. The sensor measured only one wind direction which affected the results of the predicted mean vote (PMV) in the buildings. However, given the limited availability of devices for the measurement, it was selected to record the indoor air velocity. For the purpose of measuring the mean radiant temperature (MRT), various methods have been suggested in the literature [37]. The MRT is typically measured by a black globe or surface temperature methods. However, in the current study, the surface temperature method was selected as it is a faster method due to quicker response of sensors. Using sensors to monitor surface temperature is less intrusive, but it has some challenges because of view factors, sensor deployment, and accuracy. Therefore, for the purpose of measuring and calculating MRT, we measured the surface temperature of all rooms in both cases by a Testo-925 (Beerlin, Germany) sensor with $\pm 0.5^{\circ} \mathrm{C}$ accuracy. Then, the averages of recorded data for each house are reported as final data in the results of this study. Notably, all the data loggers and sensors were calibrated prior to the field measurement. Figure 10 shows the sensors and data loggers used for the purpose of data collection. 


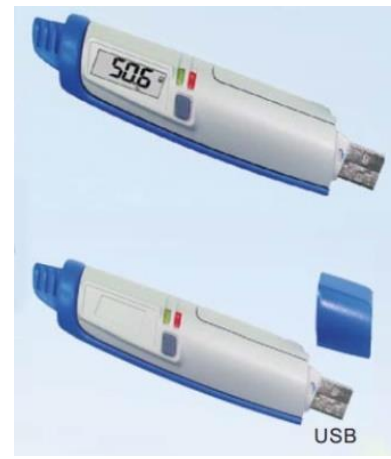

MIC-98583

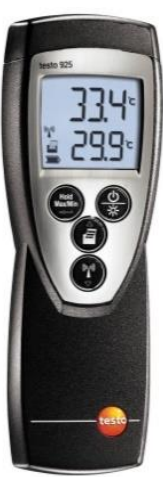

Testo-925

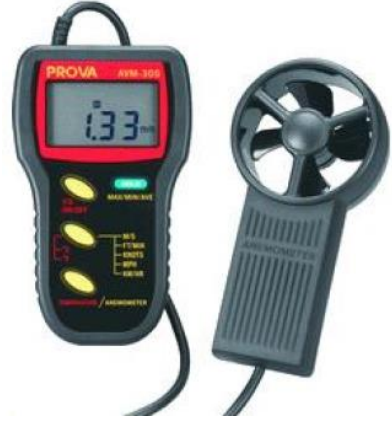

AVM-305

Figure 10. Sensors and data loggers used for the data collection.

\subsection{Experimental Test Conditions}

Two residential buildings in the ancient urban structure of Bushehr were selected. They were selected to evaluate the thermal comfort conditions with regard to older elements that were used to respond to micro-climate. A house on the seashore and another house inside the ancient urban structure were selected, as shown in Figure 1. Tabib's and Nozari's houses were selected because various passive strategies have been implemented in these older houses. Full-scale field measurement was conducted in the selected houses to assess how those applied elements could promote indoor thermal condition.

Tabib's and Nozari's houses belong to the Qajar era and are located in the historical part of town as shown in Figure 1. Tabib's house has a distance of $10 \mathrm{~m}$ from the sea (Persian Gulf) near the coast and has two floors (ground floor and first floor). It was designed with a central courtyard. The building was built using older building materials such as coral stone and mortar, plaster and rooftops, as shot by mangrove poles and special furring. Different floors were connected by spiral stairs form and the four sides of the building have been linked together as illustrated in Table 2.

Table 2. Plans and sections of Tabib's and Nozari's houses.

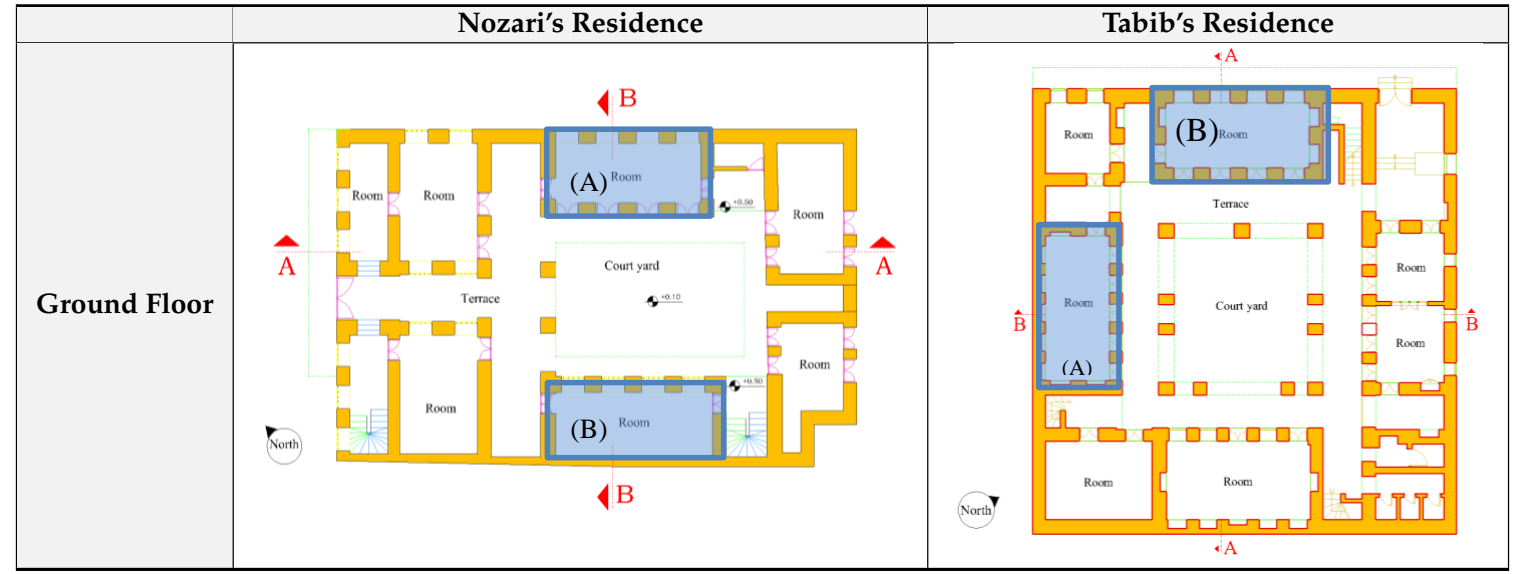


Table 2. Cont.

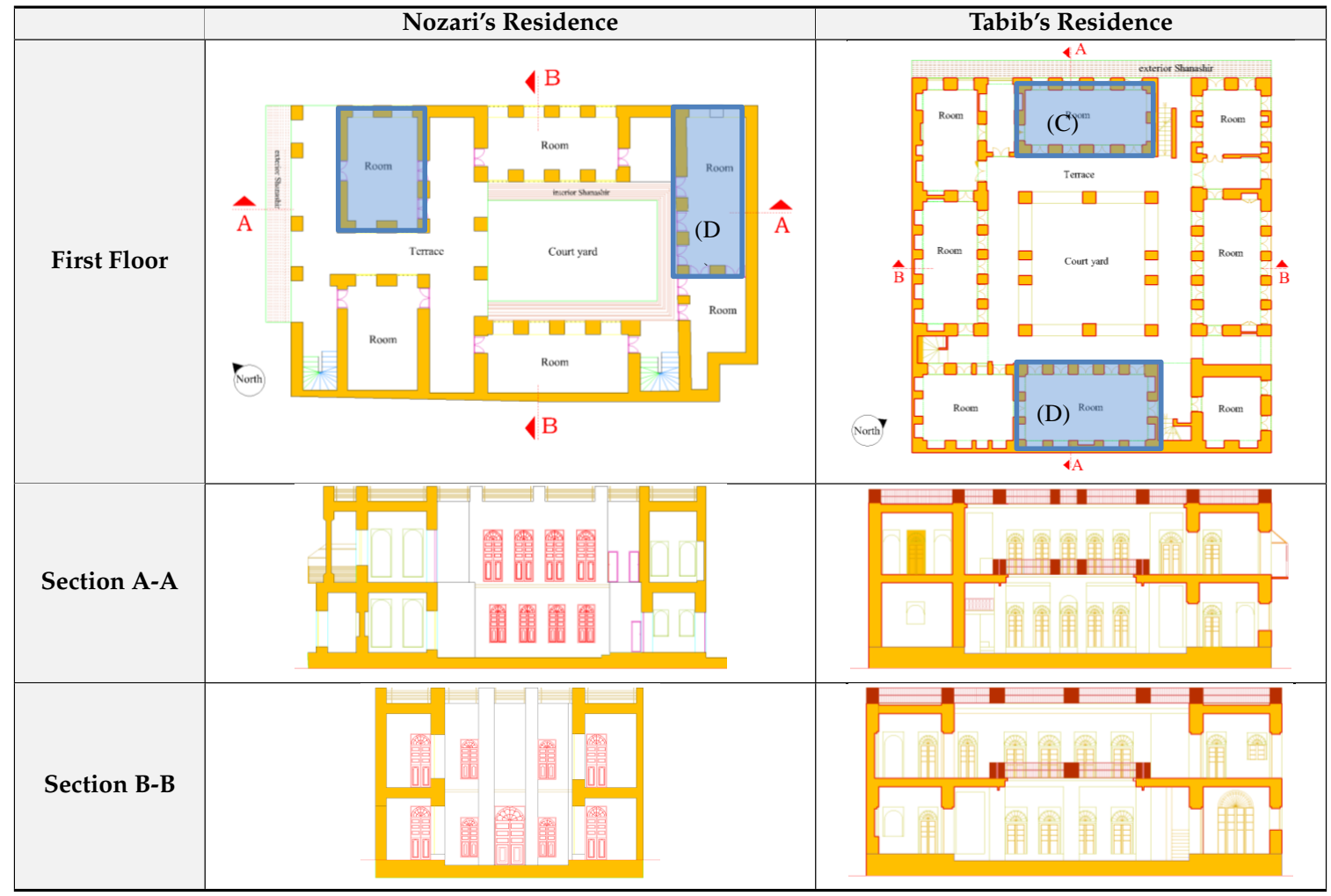

In a similar architectural plan, Nozari's house has two floors. It was designed with a central courtyard. Different floors of the building are connected by stairs and linked the two sides of the yard (Table 2). The structure was made of coral stone and mortar, plaster, beams, and flat rooftops (mangrove and shingle). All rooms have a rectangular design and were built in connection with the surrounding spaces. The pure architecture of the building with a number of openings in the building, open spaces, and semi-open spaces, and their direct relation with the outdoor environment lead the possibility of establishing natural ventilation for both studied houses. The selected houses have the most important features for the micro-climate of Bushehr. This is the main reason for selecting these houses for field measurement. The results of the experiment show how these elements have directly impacted the indoor thermal condition.

The rooms that were selected for field measurement are shown in Table 2. The reason for selecting these rooms was their close proximity to the older features. As is clear in Table 2, the selected rooms can be divided into three categories. First, there were rooms that were adjacent to the Shenashir (rooms $\mathrm{C}$ in both houses). Second, there were rooms that were surrounded by terraces such as rooms A and B in both houses on the ground floor. Finally, there were rooms that were equipped with both Shenashir and terraces. They were commonly on the first floor in both houses. Since the main purpose of this study was evaluating thermal comfort by focusing on older elements, those rooms were the most relevant choices. The reason was that they could demonstrate the pure effect of older elements on the indoor environmental conditions of adjacent rooms.

Temperature, relative humidity, wind velocity, and MRT were measured during one month. This period was based on the standard period that has been recommended in previous studies. For instance, in a study in Malaysia, Aflaki et al. [38] evaluated the indoor thermal condition for a high-rise building for a period of one month. In another study in Singapore, Liping and Hien [39] examined indoor ventilation in the naturally ventilated flats over three weeks. They selected a total number of six residential flats on different levels. Although the experiment was carried out for a month, some representative days were selected to avoid redundant analysis. It was assumed that 
these days in the hottest month clearly present the overall condition of rooms during the hot season. Therefore, the selected days were August 30 and September 1, 4, 16, 23, 27, and 30 of 2016 at 11:00 a.m. Based on the meteorological data, this time and these days were the hottest days during the selected month. The measurements were taken at the center of the selected rooms. Sensor height in each room was $0.8 \mathrm{~m}$, equivalent to the height of the head when sedentary activities are performed. The location of sensors in the courtyard was at the center and the height was adjusted to $1.5 \mathrm{~m}$ above the ground.

\section{Results and Discussion}

The thermal environment could significantly affect human health [40]. Therefore, in the current study, the effect of environmental parameters, including indoor air temperature, relative humidity, and indoor air velocity on the thermal condition of houses were investigated. As shown in Figure 11, the results of air temperature are presented for the selected days. Based on the results, the indoor air temperature for all rooms was lower than the outdoor temperature. The minimum temperatures of the rooms on August 30 and September 4 in Tabib's rooms were $28^{\circ} \mathrm{C}$ and $28.6^{\circ} \mathrm{C}$, respectively. The temperature differences between inside and outside were $2.2^{\circ} \mathrm{C}$ and $3.4^{\circ} \mathrm{C}$, respectively. This was due to the external Shenashir and semi-open spaces that were around the rooms. They created effective shadings surrounding the rooms. The lowest temperature of the rooms was recorded on September 1 and 16 , at $28.2{ }^{\circ} \mathrm{C}, 29.1{ }^{\circ} \mathrm{C}$, in the selected rooms at Nozari's house, respectively. Results for rooms in Tabib's house revealed tangible differences in temperature. Temperature differences between inside and outside were $3.4^{\circ} \mathrm{C}$ and $3.1^{\circ} \mathrm{C}$ on September 1 and 16, respectively, due to the external Shenashir, semi-open spaces, and terrace around the rooms.

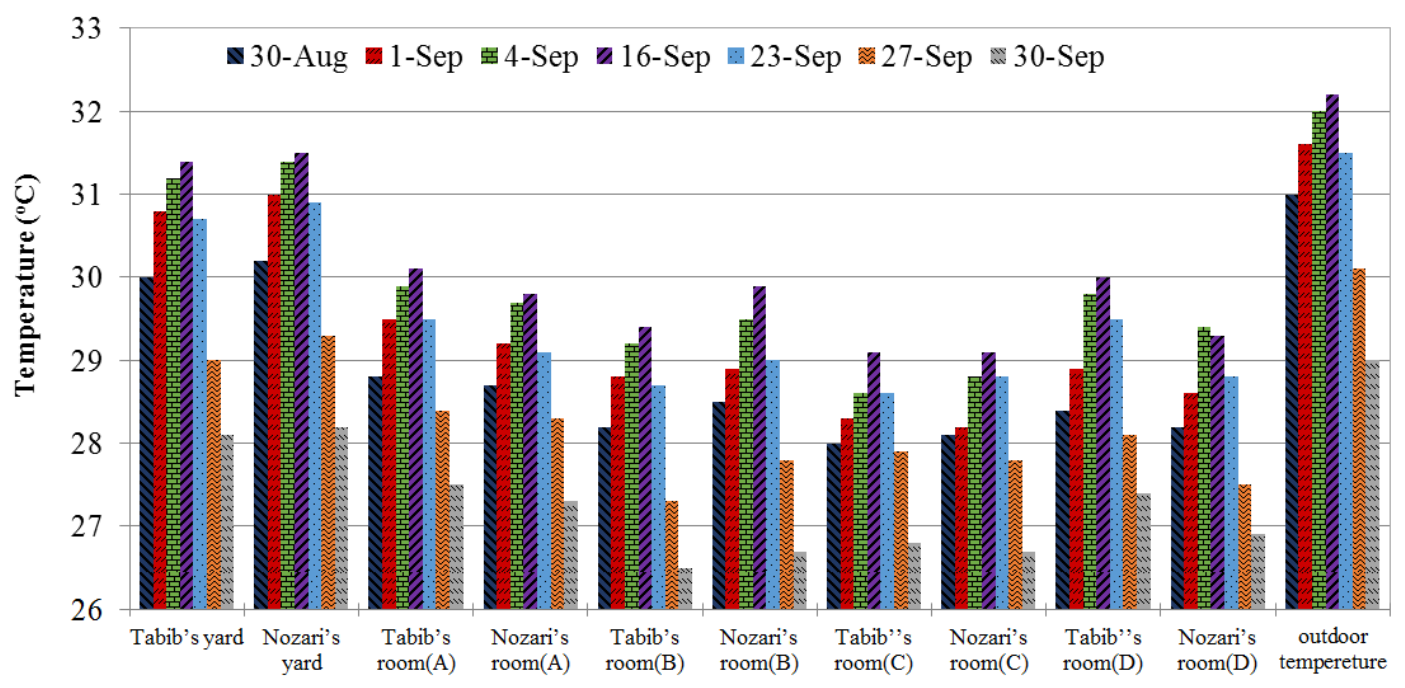

Figure 11. Temperature of rooms measured for different days and different spaces at 1:00 p.m.

More investigation into the selected rooms (A, B, and D) in Tabib's house showed that the indoor air temperature was lower than the outdoor temperature on all studied days because they have portico, terrace, semi-open spaces, and vertical and horizontal shading devices that created shadings. In Nozari's house, temperatures in rooms A and B were lower than the outdoor temperature because they had semi-open spaces and vertical shading devices. Also, room D used interior Shenashir and semi-open space. Interior Shenashir provided more shade and consequently decreased the indoor air temperature.

Figure 12 shows the average temperature of the spaces on the selected days. Based on Figures 11 and 12 , the central courtyard of houses had a temperature about $0.8^{\circ} \mathrm{C}$ lower than the outdoor temperature. This reflects the central courtyard impact on older houses. According to Figure 12, the temperature in the central courtyard of Tabib's house was 1.5\% lower than in Nozari's courtyard. This was due to more greenery, which prevented solar radiation penetration, especially during the afternoon. 


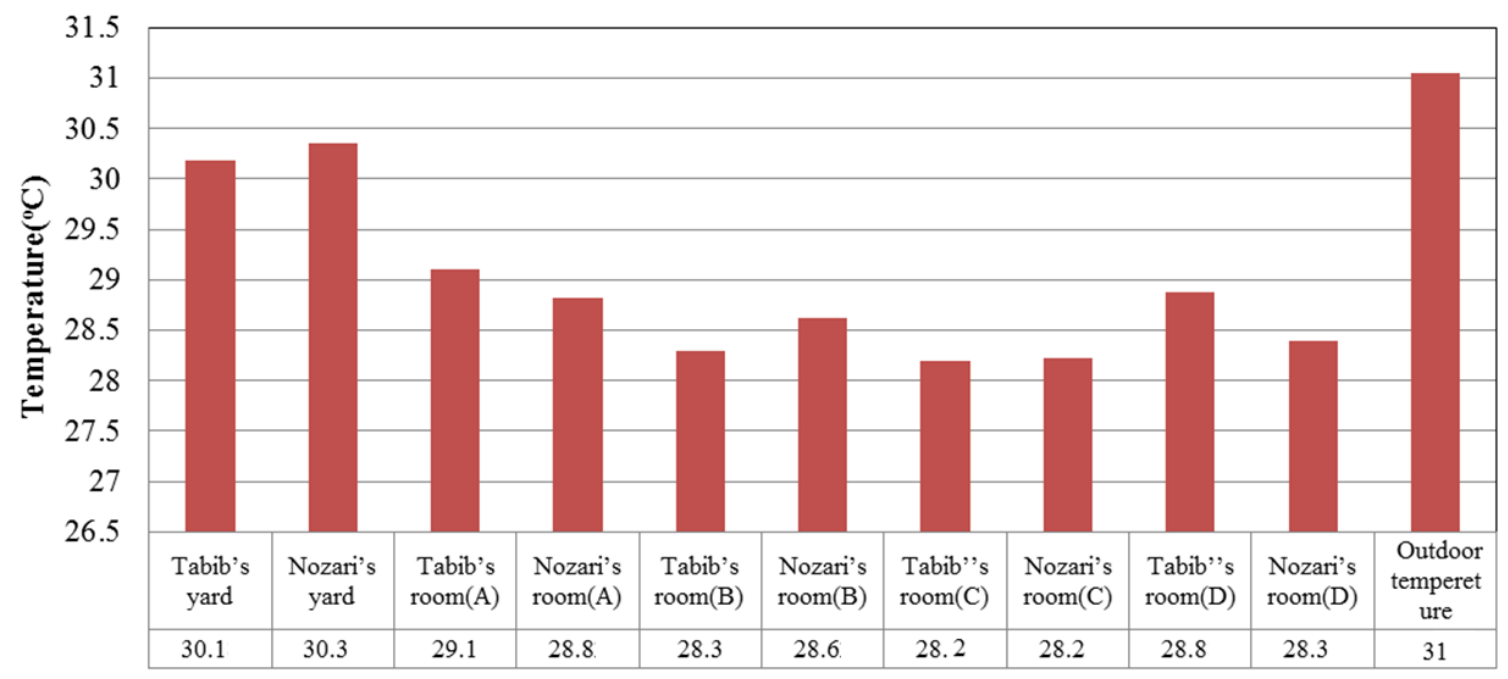

Figure 12. Average temperature of spaces during test days (August 30 and September 1, 4, 16, 23, 27, and 30, 2016).

The mean air temperature of the rooms in Tabib's house was $2.4^{\circ} \mathrm{C}$ lower than the outside temperature. This was the same as recorded in Nozari's house, where the average indoor temperature of the rooms was $2.6{ }^{\circ} \mathrm{C}$ lower than the outdoor temperature. This is because they used older elements to create shade, such as vertical and horizontal shading devices, portico, semi-open space, vertical and horizontal canopies, and external and interior Shenashir to reduce solar penetration. Also, they used a light color on the exterior parts of the buildings that contributed to the lower temperature. Furthermore, the selected buildings used materials with low thermal conductivity, such as wood in the ceiling, and implemented windows in order to reduce heat transmittance from the outside. The light color on the exterior parts of the buildings and materials with low thermal conductivity were used in other studies [19]. Also, as stated by Du et al. [25], semi-open spaces were applied in older Chinese houses to reduce temperature and create thermal comfort. Therefore, all these strategies have been evaluated numerically to identify their effectiveness in older houses.

Figures 13 and 14 show mean radiant temperature and the average of the mean radiant temperature measured for all spaces for different days, respectively. Based on Figure 13, the MRT of Tabib's room was $28.6^{\circ} \mathrm{C}$ on August 30, and the difference between MRT and air temperature of Tabib's room was $0.6^{\circ} \mathrm{C}$, which was low and constant. According to Figure 14, the difference in average mean MRT of the studied rooms with outdoor temperature was $0.6^{\circ} \mathrm{C}$. This is due to several effects including the shading, light color for the external and internal walls, and local materials (coral stone and gypsum), which kept indoor air temperature constant. Also, the wide thickness of external walls and applying materials with low thermal conductivity, such as wood in ceilings and windows, significantly reduced heat transfer. 


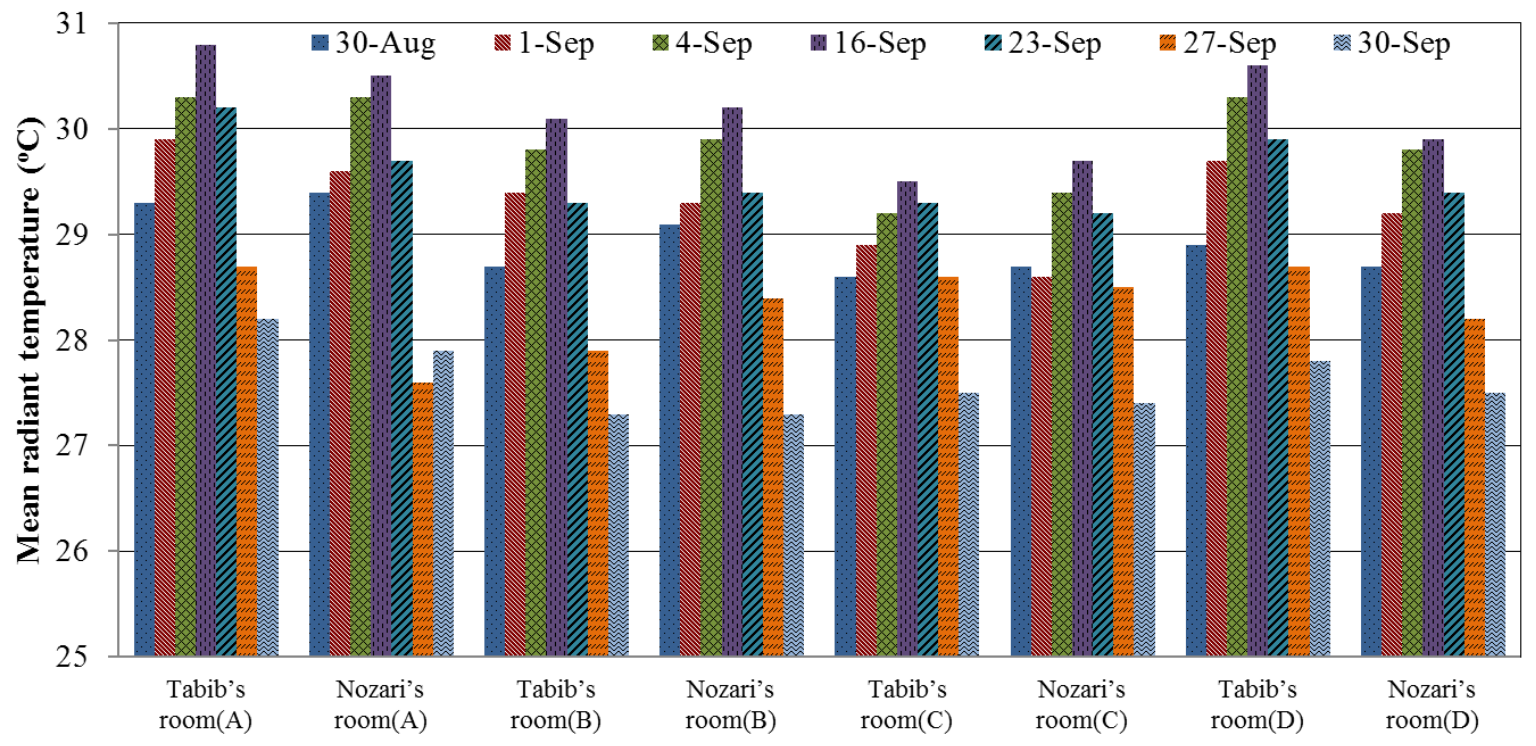

Figure 13. Mean Radiant Temperature (MRT) of rooms measured for different days in 2016.

According to Figure 14, the average MRT of Tabib's rooms was almost equal to Nozari's rooms. The average MRT of rooms on the ground floor in Tabib's house (Tabib A and B) was higher than the MRT of rooms on the ground floor of Nozari's house (Nozari A and B). The mean MRT of rooms at the first floor in Tabib's house (Tabib C and D) was higher than the MRT of the ground floor of Nozari's house (Nozari C and D) by about $0.7 \%$, which indicates that they were low. Also, the MRT of the studied houses was nearly similar.

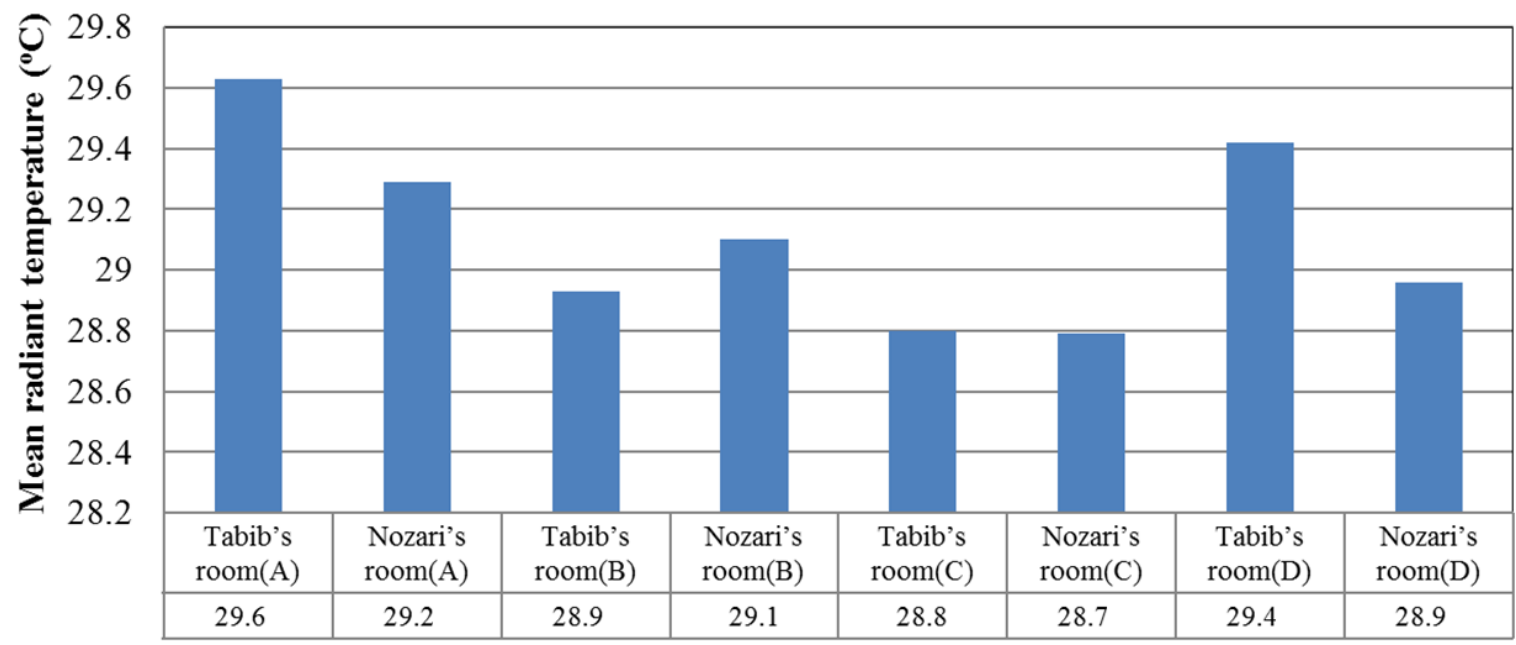

Figure 14. Average Mean Radiant Temperature (MRT) of spaces during test days (August 30 and, September 1, 4, 16, 23, 27, and 30, 2016).

According to Figure 15, maximum indoor air speed in Tabib's room (B) on August 30 was $0.7 \mathrm{~m} / \mathrm{s}$. According to the results, the wind speed difference between inside and outside was $0.6 \mathrm{~m} / \mathrm{s}$. In addition, the relative humidity was $22.7 \%$ lower than the outdoor relative humidity (Figure 16), which was constant. This was due to the location of the room where it faced the Persian Gulf, so it received sea breeze that created suitable ventilation. 


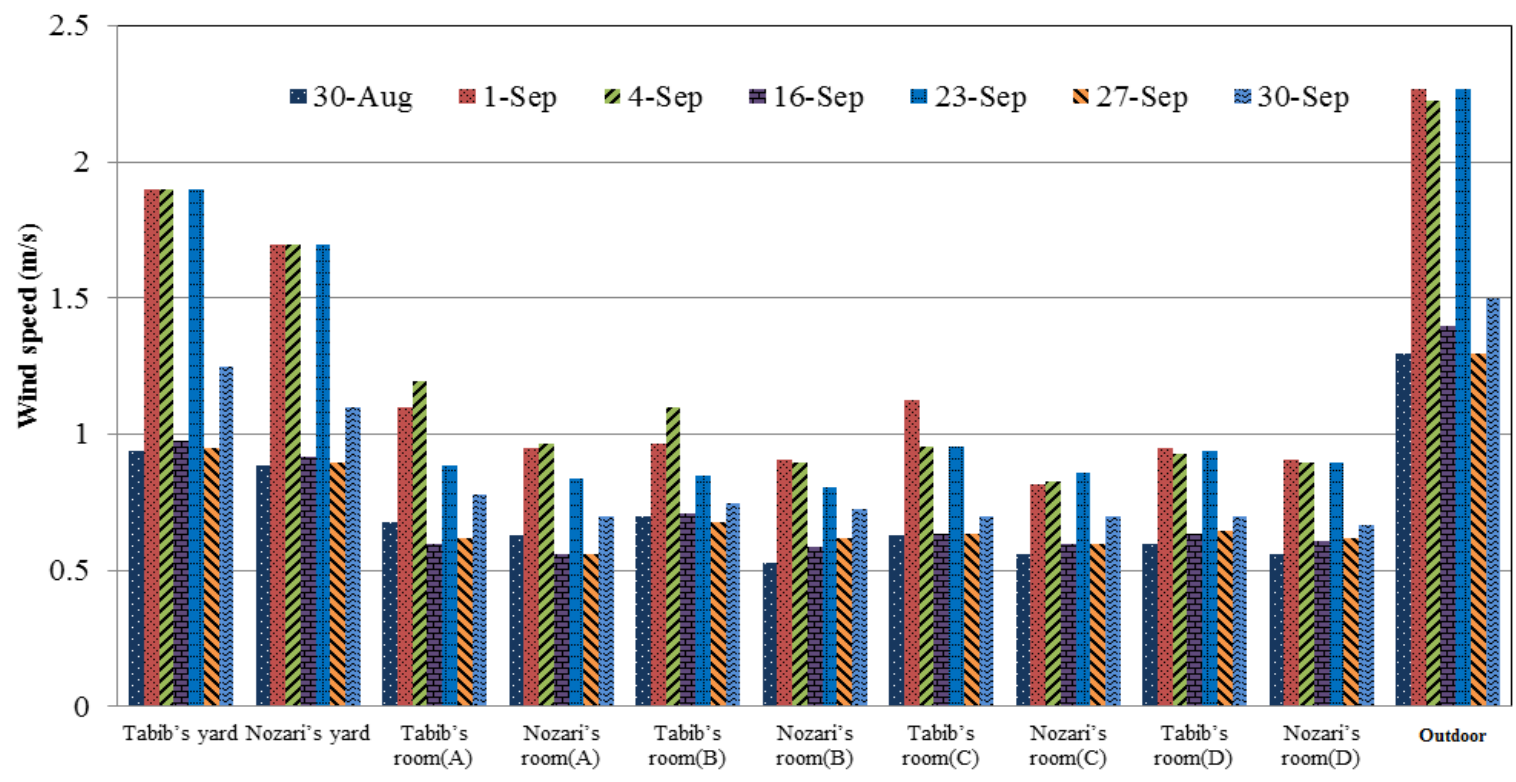

Figure 15. Wind speed of rooms measured for different days, 2016.

The maximum wind speed of Tabib's room (C) on September 1, 2016 was $1.13 \mathrm{~m} / \mathrm{s}$ and the wind speed difference between inside and outside was $1.14 \mathrm{~m} / \mathrm{s}$. Additionally, the relative humidity of Tabib's room (C) was 19\% lower than the outdoor relative humidity (Figure 16). The reason for this was the location of the room $(\mathrm{C})$, where it received sufficient sea breeze. The amount of indoor air velocity for Tabib's rooms A, B, and C was higher than $1 \mathrm{~m} / \mathrm{s}$ on such windy days. Although this amount of wind reduces the relative humidity, it increases the risk of thermal discomfort. It should be noted that wind velocity and wind direction affect the indoor air velocity in the mentioned room significantly. Based on Figure 15, the variation in wind speeds in all studied rooms was $0.53 \mathrm{~m} / \mathrm{s}$ to $1.2 \mathrm{~m} / \mathrm{s}$, which was very constant. Also, the relative humidity of the rooms was $20.5 \%$ lower than $\mathrm{RH}$ outdoor during all days (Figure 17). The result of the study was in line with the study by Sapian et al. [41]. According to their study in a naturally ventilated building, the thermal comfort condition can be achieved in a hot and humid climate where the indoor air temperature ranged between $26.0^{\circ} \mathrm{C}$ to $29.9^{\circ} \mathrm{C}$ and the indoor air velocity was $0.5 \mathrm{~ms}^{-1}$ to $1.0 \mathrm{~ms}^{-1}$. The relative humidity must not exceed $90 \%$ in this condition in order to sustain comfort. Moreover, according to the recommendation by ASHRAE [42], comfort can be attained when a minimum air velocity of $0.15 \mathrm{~ms}^{-1}$ blows in a room where the indoor air temperature is between $23{ }^{\circ} \mathrm{C}$ to $26^{\circ} \mathrm{C}$ and the relative humidity is less than $70 \%$. Based on the results, thermal comfort was achieved in the studied rooms because of the relevant location of the rooms. The rooms around a central courtyard received wind flow from the central courtyard or the alleys around the house. In addition, by accurate placement of windows and doors facing each other, further ventilation in the selected building was achieved. 


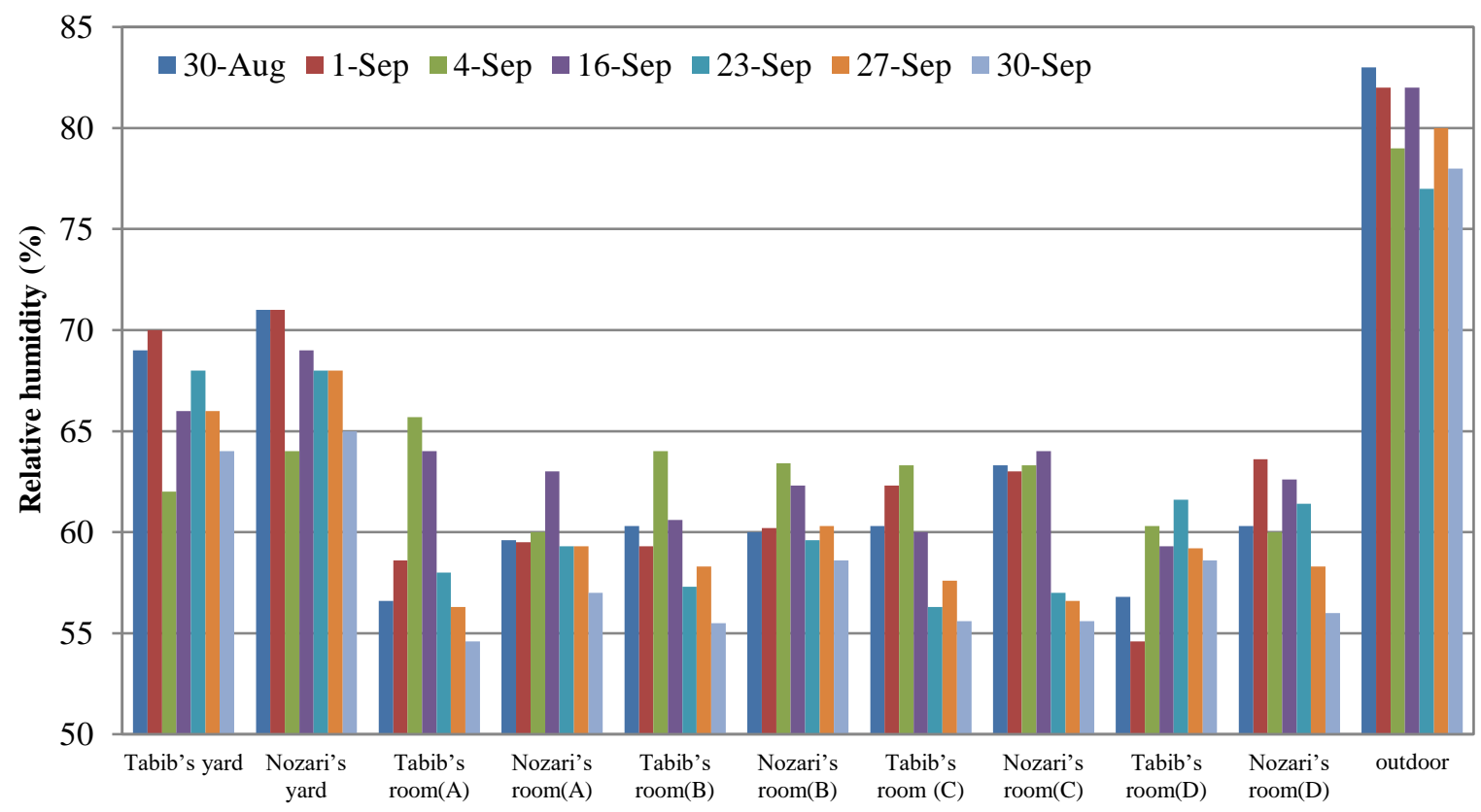

Figure 16. Relative humidity of rooms measured for different days, 2016.

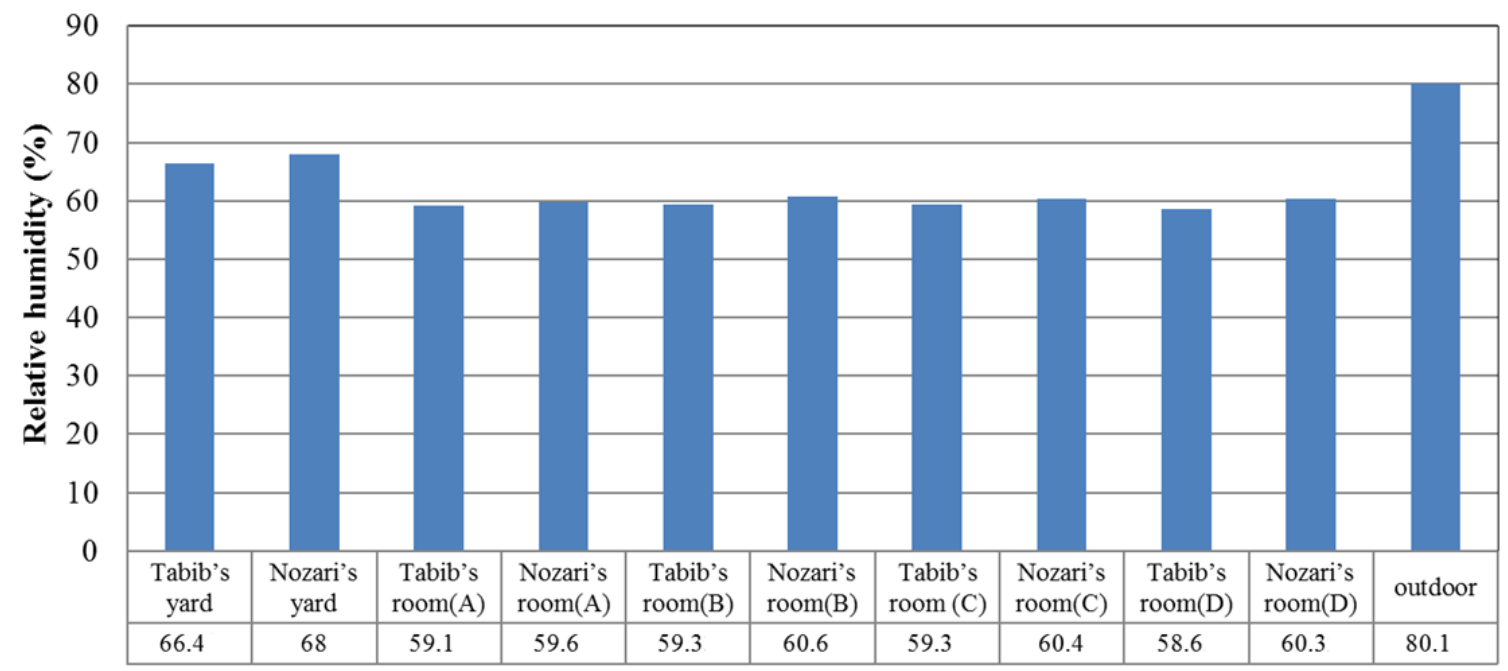

Figure 17. Average relative humidity of spaces during test days (August 30 and, September 1, 4, 16, 23, 27 , and 30, 2016).

Based on Figure 15, wind speeds of Nozari's house yard and Tabib's house yard were $0.89 \mathrm{~m} / \mathrm{s}$ and $0.94 \mathrm{~m} / \mathrm{s}$ on August 30, 2016, respectively. Also, the relative humidity of Nozari's house yard and Tabib's house yard were $12 \%$ and 14\% lower than outdoor relative humidity on August 30, 2016, respectively (Figure 16). This ascertained that courtyards were relevant elements that work sufficiently in hot-humid climates. Based on Figure 16, the mean wind speed of the courtyards was $1.34 \mathrm{~m} / \mathrm{s}$, which was about $0.4 \mathrm{~m} / \mathrm{s}$ lower than the outside. Also, the mean relative humidity of courtyards was about $12.9 \%$ lower than the outside. Thus, the courtyard in older houses effectively moderates micro-climate. The result was in line with the outcomes that were reported in other studies in different regions with hot-humid climates $[13,15,21,23,27]$. According to Figure 18, the wind speed of Tabib's house yard was $8.6 \%$ higher than Nozari's house yard. Also, the mean wind speed of the rooms in Tabib's house was lower than the outside wind speed, which was due to Tabib's house location, as it faces the sea. 


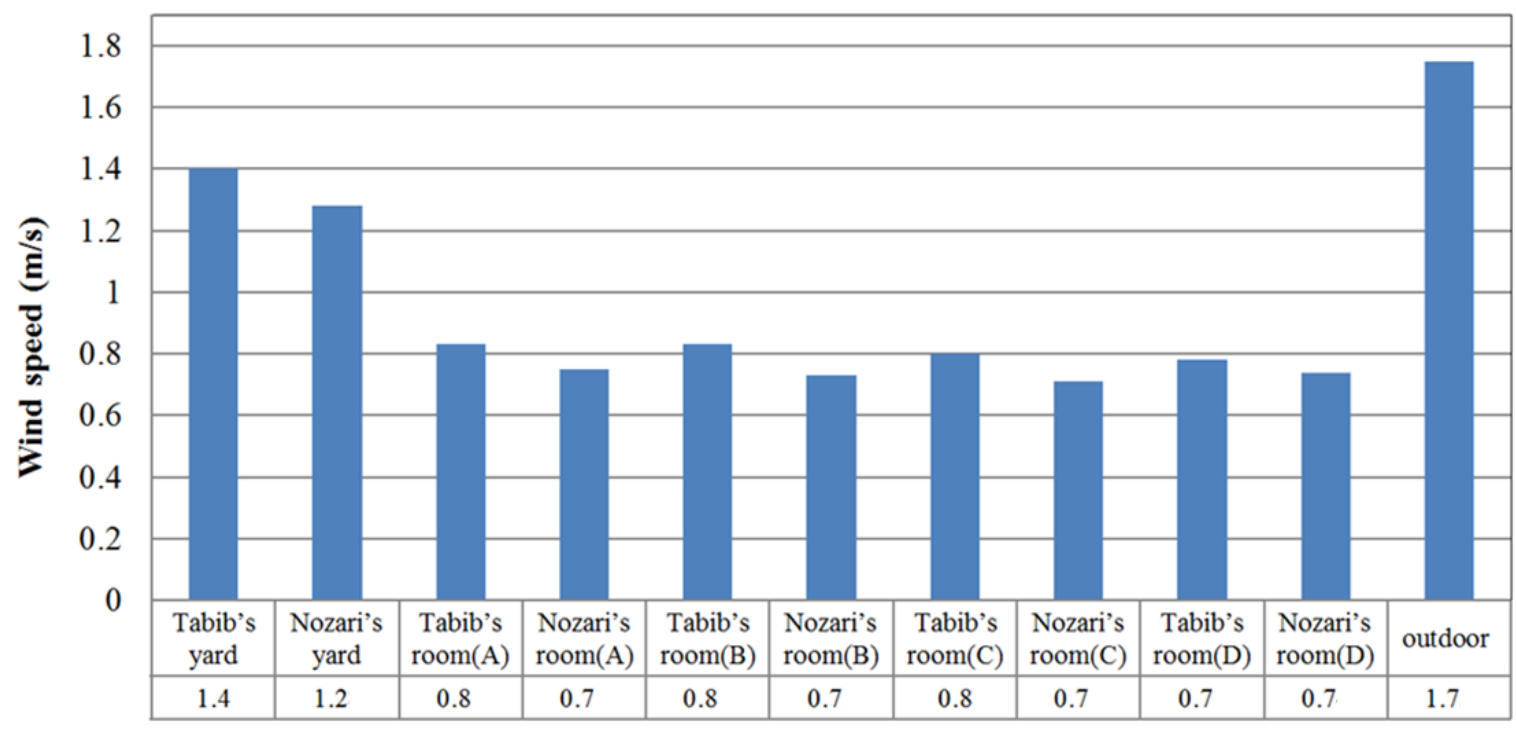

Figure 18. Average wind speed of spaces during test days effectively (August 30 and, September 1, 4, $16,23,27$, and 30, 2016).

After the analysis of air temperature, Mean radiant temperature (MRT), wind speed, and relative humidity, the value of the Predicted Mean Vote (PMV) and Predicted Percentage of Dissatisfied (PPD) were calculated. Many studies investigated the calculation of PMV. Fanger's model for thermal comfort is one of the main models that has been used in the majority of studies $[43,44]$. In the current study, the metabolic rate for the calculated PMV and PPD was assumed to be0.9. Metabolic rate is the average of light working, seated, relaxed, sleeping, and reclining according to ISO 7730 for sedentary activities [45]. Also, clothing level was assumed to be 0.5 based on ISO 7730 [45] for typical summer indoor clothing.

Figure 19 shows the values of PMV for the rooms for the test days. According to Figure 19, the PMV index of all rooms was under one. According to Table 3, ISO 7730 specifies three different categories of thermal comfort depending upon PMV ranges. The comparison of results with the above-mentioned standard confirms that the measured rooms that were in different classes depended on the locations. It should be noted that on such hot days the PMV value was not in the specified classes. For instance, the PMV values in Tabib's room A and Nozari's rooms A and B on September 16, 2016 were not in the range specified by ISO7730. However, the values of PMV for other rooms on different days were mostly within classes $\mathrm{A}$ and $\mathrm{B}$, which were in an acceptable range according to ISO 7730 [45]. Also, the value of PMV of the rooms had a diurnal variation of 0.55 on September 16. On this date, the lowest PMV of the rooms was in Tabib's room C, and the highest was for Tabib's room A. PMV of the rooms had a diurnal variation of 0.35 on September 23, 2016. PMV of all of the rooms was under 0.5 on September 27 and 30. 


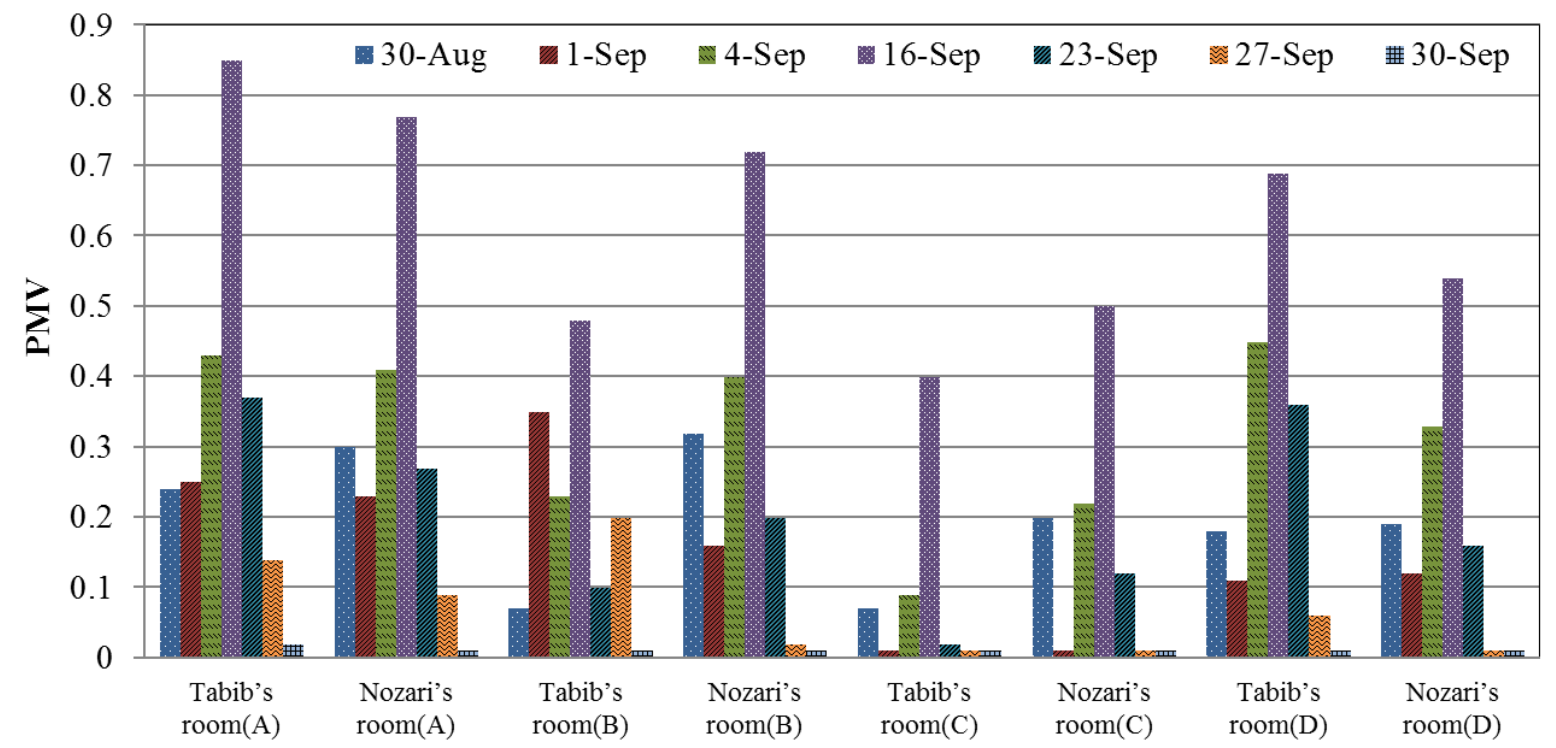

Figure 19. Predicted Mean Vote (PMV) index measured of the rooms during the test.

Table 3. Different categories of thermal comfort based on the Predicted Mean Vote (PMV) range [46,47].

\begin{tabular}{cccc}
\hline Class & A & B & C \\
\hline PMV & $-0.2<$ PMV $<0.2$ & $-0.5<$ PMV $<0.5$ & $-0.7<$ PMV $<0.7$ \\
PPD & $<6$ & $<10$ & $<15$ \\
\hline
\end{tabular}

Figure 20 shows a comparison of PPD in the studied rooms for the test days. According to Figure 20, the PPD index of all rooms was under 20\%, which was in an acceptable range according to ISO 7730 [45]. Also, the PPD of the selected rooms had a diurnal variation of $12 \%$ on September 16, 2016. On this date, the lowest PPD was in Tabib's room C, and the highest PPD was in Tabib's room ). Also, on September 23, the minimum PMV was in Tabib's rooms B and C and Nozari's room C. On the other hand, the highest PMV was for Tabib's rooms A and D. The PPD of all rooms was under 5\% on September 27 and 30.

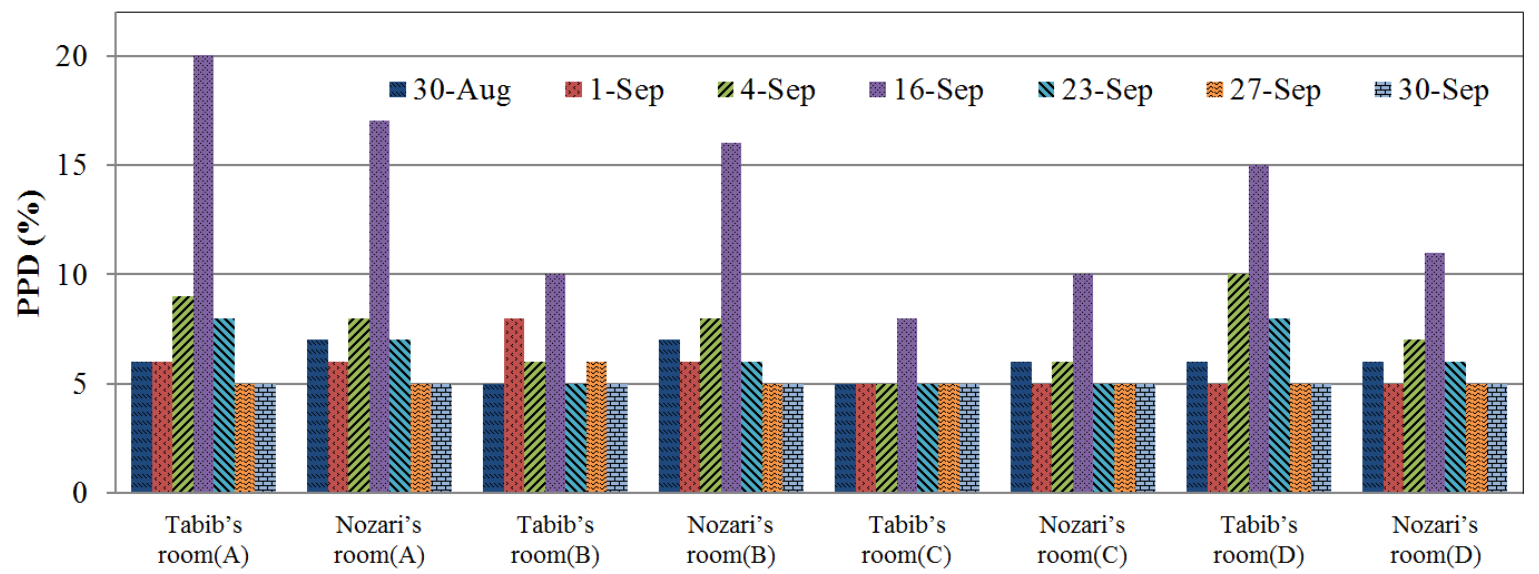

Figure 20. Predicted Percentage of Dissatisfied (PPD) index of the rooms during test days (August 30 and September 1, 4, 16, 23, 27, and 30, 2016).

Figure 21 illustrates a comparison between the average measured PMV index of the studied rooms with the average of PMV calculated from the wind speed default of $0.1 \mathrm{~m} / \mathrm{s}, 0.2 \mathrm{~m} / \mathrm{s}$, and $0.3 \mathrm{~m} / \mathrm{s}$. According to Figure 21, the measured PMV of Tabib's rooms was 3.3\% lower than Nozari's rooms. Also, the measured PMV of rooms on the ground floor in Tabib's house (A and B) was 5.4\% lower than PMV of ground floor Nozari's house (Nozari A and B). 


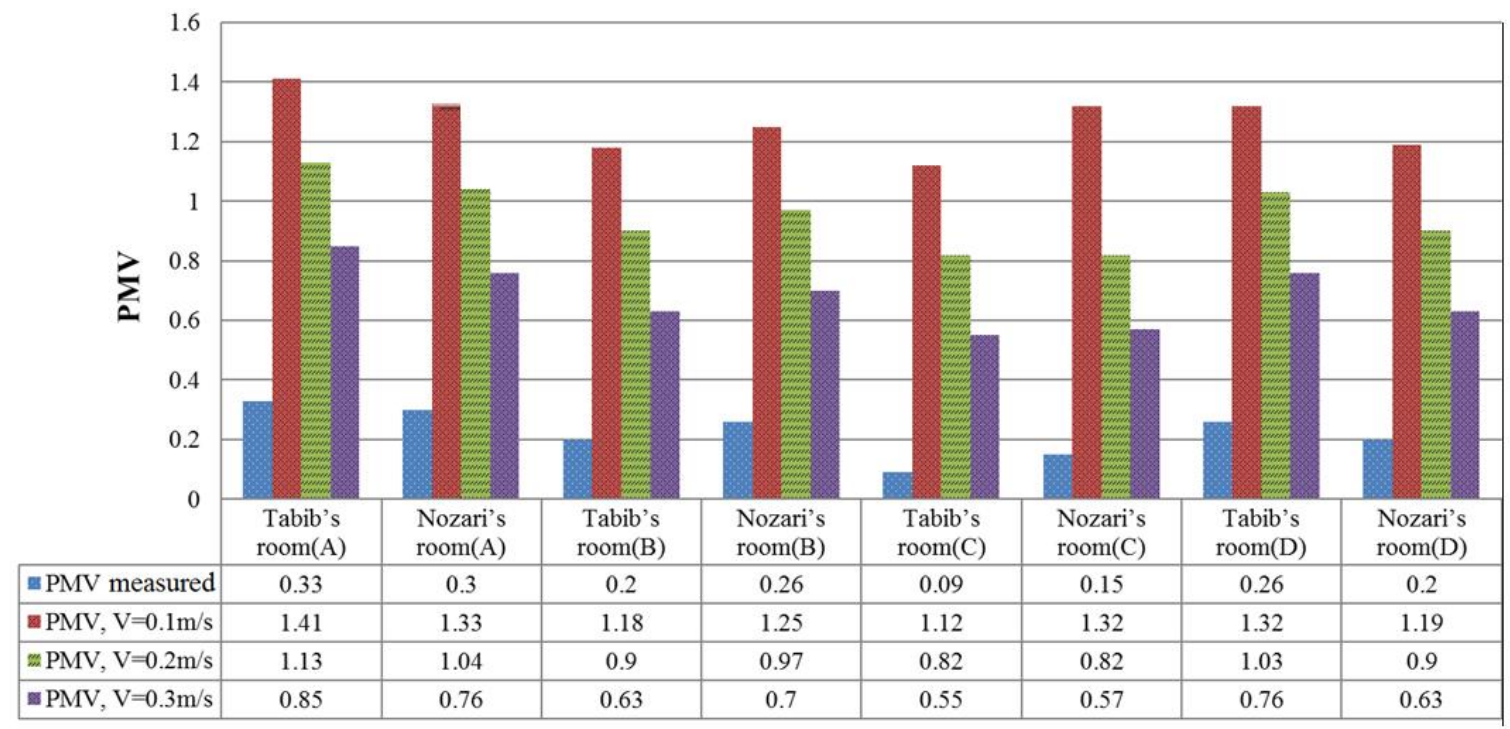

Figure 21. Comparison of averaged measured PMV index of the rooms with PMV index for default wind speed of $0.1 \mathrm{~m} / \mathrm{s}, 0.2 \mathrm{~m} / \mathrm{s}$, and $0.3 \mathrm{~m} / \mathrm{s}$ in all rooms during test days (August 30 and September 1, $4,16,23,27$, and 30, 2016).

The average PMV of the studied rooms at the first floor in Tabib's house (C and D) was equal to the average PMV of the rooms at the ground floor of Nozari's house (C and D). The measured PMV of the rooms in the selected houses was $83 \%$ better than the PMV of the rooms for a default wind speed of $0.1 \mathrm{~m} / \mathrm{s}$. Also, the measured PMV of the studied rooms was $73 \%$ better than the PMV of the rooms for a default wind speed of $0.2 \mathrm{~m} / \mathrm{s}$. Repeatedly, the measured PMV of the studied rooms were better than the PMV of the rooms for a default wind speed of $0.2 \mathrm{~m} / \mathrm{s}$, which was about $67 \%$.

Figure 22 indicates the average of the measured PPD index of the studied rooms with the average PPD for default wind speeds of $0.1 \mathrm{~m} / \mathrm{s}, 0.2 \mathrm{~m} / \mathrm{s}$, and $0.3 \mathrm{~m} / \mathrm{s}$. According to Figure 22, the measured PPD of rooms in both houses was lower than $10 \%$, and it was in an acceptable range. The mean PPD of the first floor and the ground floor of rooms in both houses was approximately equal. The measured PPD of the rooms was $32.1 \%$ lower than the PPD of the rooms when the default wind speed was $0.1 \mathrm{~m} / \mathrm{s}$. In addition, the measured PPD of the rooms was 19.6\% lower than the PPD of the rooms when the default wind speed was $0.2 \mathrm{~m} / \mathrm{s}$.

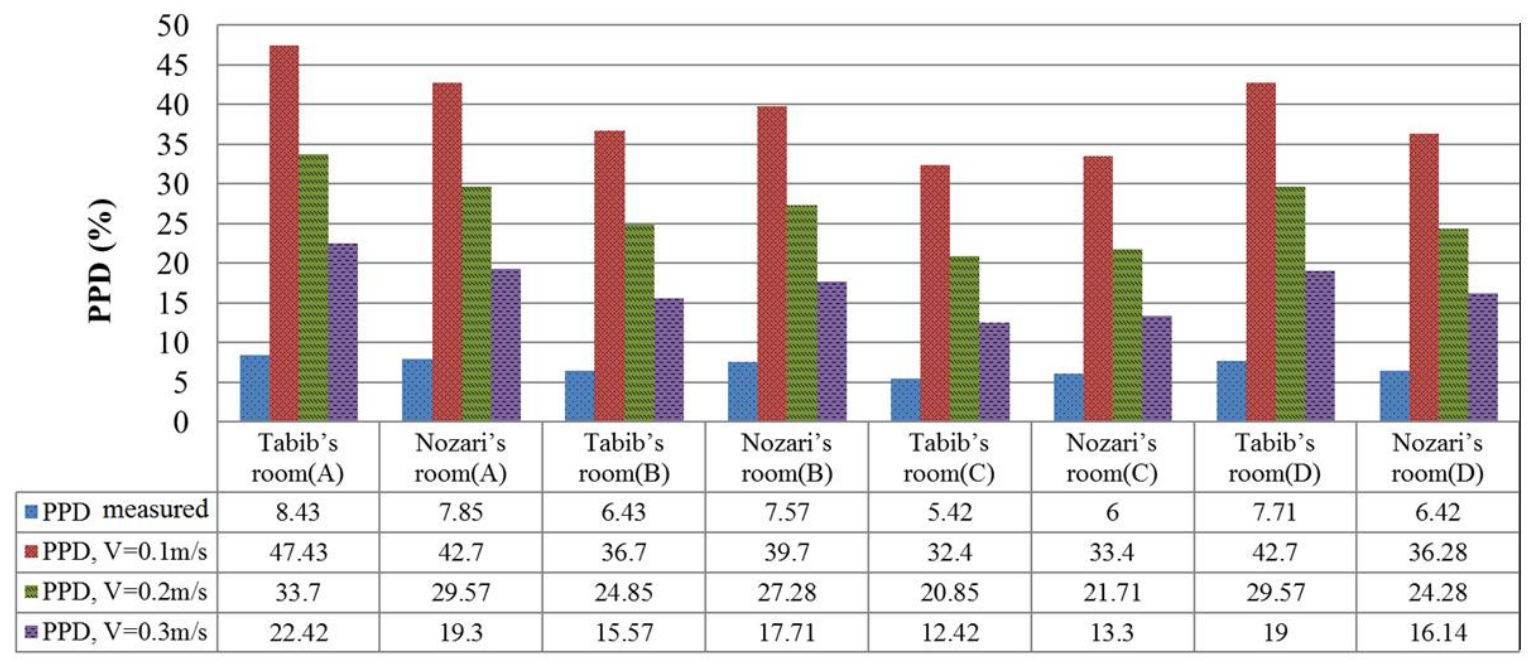

Figure 22. Comparison of averaged measured PPD index of the rooms with PPD index for default wind speed of $0.1 \mathrm{~m} / \mathrm{s}, 0.2 \mathrm{~m} / \mathrm{s}$ and $0.3 \mathrm{~m} / \mathrm{s}$ in all rooms during test days (August 30 and September 1, $4,16,23,27$, and 30, 2016). 
Figures 20 and 21 reveal that the main factor in the creation of indoor thermal comfort in older buildings was natural ventilation.

The results of this study are in line with the results of previous studies that focused on the application of passive design elements in buildings in different parts of the world [10,11,21,22,28,29]. Thus, we concluded that the current study contributes to the knowledge in this field by evaluating the building performance in the city of Bushehr in Iran, where master builders have used passive architectural elements through in older architecture in order to attain thermal comfort.

\section{Conclusions}

We investigated passive design strategies in houses located in the ancient urban city of Bushehr. In addition, we evaluated thermal comfort conditions in two selected houses in the city. Older houses in the hot-humid region were constructed based on climatic factors. Based on the results of full-scale measurement, the mean measured PMV of Tabib's rooms (a house near the sea (was 0.88 and the mean measured PMV of Nozari's rooms (a house in the traditional city) was 0.91 . The measured PMV of Tabib's rooms was 3.3\% lower than Nozari's rooms because Tabib's house is located adjacent to the Persian Gulf and received more sea breeze than Nozari's house. The measured PPD of rooms in both houses were lower than $10 \%$, which was in the acceptable range. The mean PPD of the first floor and ground floor of the studied rooms in both houses were approximately equal. Based on the documentary study and field measurement, the following conclusions were drawn.

(1) The main factor in creating indoor thermal comfort in older buildings in hot-humid climates in summer is using natural ventilation. Wind-induced ventilation by the difference in pressure (cross ventilation) was the main reason for wind circulation inside the studied houses.

(2) It is convenient to reduce temperature by using a light color on the exterior parts of the buildings, which contributes to the mitigation of indoor air temperature.

(3) Using materials with low thermal conductivity, such as wood in the ceilings and windows in the buildings, improve thermal comfort.

(4) Using local materials (coral stone and gypsum) in the external and internal wall of the building reduces indoor temperature and provides acceptable conditions for occupants.

(5) Passive elements in the older architecture play an important role in providing thermal comfort. Based on a review of the literature and the quantitative results of this study, effective elements were identified. Using vertical and horizontal canopies, portico, and semi-open space, and external and interior Shenashir could significantly reduce indoor air temperature.

(6) External Shenashir creates shadow and controls the air flow to the interior. Also, it enables maximum use of the wind flow and the sea breeze to reduce the humidity in the building. Its function is based on the difference in air pressure. As the air pressure on the surfaces of Shenashir is higher than the indoor air pressure, the wind circulates smoothly in the studied rooms.

(7) The central courtyard is used in older houses during summer time. Based on the results, the temperature of the yard is lower than the ambient outdoor air temperature.

Thus, rooms around a central courtyard can use this advantage to provide acceptable indoor thermal conditions. These are the legacies of the our ancestors that can be used in modern buildings; e.g., cross ventilation, using a light color on the exterior parts, adaptive materials, using canopies, portico, and semi-open space, external and interior Shenashir, and central courtyard. These building are also identified as guidelines for designing modern architecture in hot-humid climates. These techniques will help reduce energy consumption and provide environmentally-friendly buildings. 
Author Contributions: Conceptualization, J.S.; Methodology, J.S. and M.Y.; Formal analysis, J.S. and A.A.; Investigation, M.Y. and A.H.; Resources, M.Y. and A.H.; Data curation, J.S. and A.A.; Writing-original draft preparation, J.S. and A.A.; Writing-review and editing, J.S. and A.A.; Supervision, M.Y.

Funding: The authors would like to appreciate "Iran's National Elites Foundation" for the financial supports of the current project. This article has been prepared in the Shiraz University under the consideration of above mentioned organization.

Conflicts of Interest: The authors declare no conflict of interest.

\section{References}

1. Moonen, P.; Defraeye, T.; Dorer, V.; Blocken, B.; Carmeliet, J. Urban Physics: Effect of the micro-climate on comfort, health and energy demand. Front. Archit. Res. 2012, 1, 197-228. [CrossRef]

2. Vega-Azamar, R.E.; Glaus, M.; Hausler, R.; Oropeza-García, N.A.; Romero-López, R. An emergy analysis for urban environmental sustainability assessment, the Island of Montreal, Canada. Landsc. Urban Plan. 2013, 118, 18-28. [CrossRef]

3. Chávez, J.R.G.; Melchor, F.F. Application of combined passive cooling and passive heating techniques to achieve thermal comfort in a hot dry climate. Energy Procedia. 2014, 57, 1669-1676. [CrossRef]

4. Afshari, H. Design Fundamentals in the hot and humid climate of Iran: The case of Khoramshahr. Asian Cult. Hist. 2012, 4, 65. [CrossRef]

5. Foruzanmehr, A. Summer-time thermal comfort in older earth dwellings in Yazd, Iran. Int. J. Sustain. Des. 2012, 2, 46. [CrossRef]

6. Ranjbar, E.; Pourjafar, M.; Khaliji, K. Creative climatic design fits with the wind in Bushehr old. Bagh. Nazar. 2010, 7, 17-34.

7. Nematchoua, M.K.; Tchinda, R.; Orosa, J.A. Thermal comfort and energy consumption in modern versus traditional buildings in Cameroon: A questionnaire-based statistical study. Appl. Energy 2014, 114, 687-699. [CrossRef]

8. Dili, A.S.; Naseer, M.A.; Varghese, T.Z. Thermal comfort study of Kerala traditional residential buildings based on questionnaire survey among occupants of traditional and modern buildings. Energy Build. 2010, 42, 2139-2150. [CrossRef]

9. Ramli, N.H. Re-adaptation of Malay House Thermal Comfort Design Elements into Modern Building Elements-Case Study of Selangor Traditional Malay House \& Low Energy Building in Malaysia. Iran. J. Energy Environ. 2012, 3, 19-23. [CrossRef]

10. Sarkar, A. Study of Climate Responsive Passive Design Features in Traditional Hill Architecture of Khyah Village in Hamirpur, Himachal Pradesh, India for Indoor Thermal Comfort. J. Inst. Eng. Ser. A 2013, 94, 59-72. [CrossRef]

11. Wang, L.J.; Liu, J.P.; Liu, Y.F.; Wang, Y.Y.; Chen, J. Study on Thermal Environment of Traditional Architecture in Tropic Climate. Adv. Mater. Res. 2011, 243-249, 6857-6861. [CrossRef]

12. Labaki, L.C.; Kowaltowski, D.C.C.K. Bioclimatic and older design in urban settlements of Brazil. Build. Environ. 1998, 33, 63-77. [CrossRef]

13. Toe, D.H.C.; Kubota, T. Comparative assessment of older passive cooling techniques for improving indoor thermal comfort of modern terraced houses in hot-humid climate of Malaysia. Sol. Energy 2015, 114, 229-258. [CrossRef]

14. Borong, L.; Gang, T.; Peng, W.; Ling, S.; Yingxin, Z.; Guangkui, Z. Study on the thermal performance of the Chinese traditional older dwellings in Summer. Energy Build. 2004, 36, 73-79. [CrossRef]

15. Ryu, Y.; Kim, S.; Lee, D. The influence of wind flows on thermal comfort in the Daechung of a traditional Korean house. Build. Environ. 2009, 44, 18-26. [CrossRef]

16. Al-Hinai, H.; Batty, W.J.; Probert, S.D. Older architecture of Oman: Features that enhance thermal comfort achieved within buildings. Appl. Energy 1993, 44, 233-258. [CrossRef]

17. Saadatian, O.; Haw, L.C.; Sopian, K.; Sulaiman, M.Y. Review of windcatcher technologies. Renew. Sustain. Energy Rev. 2012, 16, 1477-1495. [CrossRef]

18. Singh, M.K.; Mahapatra, S.; Atreya, S.K. Bioclimatism and older architecture of north-east India. Build. Environ. 2009, 44, 878-888. [CrossRef] 
19. Singh, M.K.; Mahapatra, S.; Atreya, S.K. Thermal performance study and evaluation of comfort temperatures in older buildings of North-East India. Build. Environ. 2010, 45, 320-329. [CrossRef]

20. Fernandes, J.; Pimenta, C.; Mateus, R.; Silva, S.M.; Bragança, L. Contribution of portuguese older building strategies to indoor thermal comfort and occupants' perception. Buildings 2015, 5, 1242-1264. [CrossRef]

21. Fernandes, J.; Mateus, R.; Bragança, L.; Júlio, J.; Correia da Silva, J.J. Portuguese older architecture: The contribution of older materials and design approaches for sustainable construction. Archit. Sci. Rev. 2015, 58, 324-336. [CrossRef]

22. Fernandes, J.E.P.; Debaieh, M.; Mateus, R.; Silva, S.M.; Bragança, L.; Gervásio, C.; Paper, M.D.; Malm, A.I.; Approach, L.; Cycle, C. Engineering, Thermal Performance and Comfort of Older Earthen Buildings in Egypt and Portugal, 3rd Restapia, 3rd Versus; CRC Press: Sostierra, Portugal, 2017; pp. 95-100. [CrossRef]

23. Kubota, T.; Toe, D.H.C. Application of passive cooling techniques in older houses to modern urban houses: A case study of Malaysia. Procedia-Soc. Behav. Sci. 2015, 179, 29-39.

24. Climates, V.D.; Alrashed, F.; Asif, M.; Burek, S. The Role of Older Construction Techniques and Materials for Developing Zero-Energy Homes in Various Desert Climates. Buildings 2017, 7, 17. [CrossRef]

25. Du, X.; Bokel, R.; Van Den Dobbelsteen, A. Building microclimate and summer thermal comfort in free-running buildings with diverse spaces: A Chinese older house case. Build. Environ. 2014, 82, 215-227. [CrossRef]

26. Kubota, T.; Zakaria, M.A.; Abe, S.; Toe, D.H.C.; Hooi, D.; Toe, C. Thermal functions of internal courtyards in traditional Chinese shophouses in the hot-humid climate of Malaysia. Build. Environ. 2017, 112, 115-131. [CrossRef]

27. Hazbei, M.; Nematollahi, O.; Behnia, M.; Adib, Z. Reduction of energy consumption using passive architecture in hot and humid climates. Tunn. Undergr. Sp. Technol. 2015, 47, 16-27. [CrossRef]

28. Chandel, S.S.; Sharma, V.; Marwah, B.M. Review of energy ef fi cient features in older architecture for improving indoor thermal comfort conditions. Renew. Sustain. Energy Rev. 2016, 65, 459-477. [CrossRef]

29. Praseeda, K.I.; Mani, M.; Reddy, B.V.V. Assessing Impact of Material Transition and Thermal Comfort Models on Embodied and Operational Energy in Older Dwellings (India). Energy Procedia 2014, 54, 342-351. [CrossRef]

30. Beccali, M.; Strazzeri, V.; Germanà, M.L.; Melluso, V.; Galatioto, A. Vernacular and bioclimatic architecture and indoor thermal comfort implications in hot-humid climates: An overview. Renew. Sustain. Energy Rev. 2017, 82, 1-11. [CrossRef]

31. Nasrollahi, F. Office Buildings Energy Efficient: Energy Efficiency with the Architectural Design; Berlin university: Berlin, Germany, 2015. (in Persian)

32. Shahin, A.; Takapoomanesh, S. Understanding patterns of sustainable architecture in residential buildings of the historic fabric of Bushehr. Archit. Build. 2006, 10, 130-135.

33. Cheng, V.; Ng, E.; Givoni, B. Effect of envelope colour and thermal mass on indoor temperatures in hot humid climate. Sol. Energy. 2005, 78, 528-534. [CrossRef]

34. Peng, C. Survey of thermal comfort in residential buildings under natural conditions in hot humid and cold wet seasons in Nanjing. Front. Archit. Civ. Eng. China. 2010, 4, 503-511. [CrossRef]

35. Cândido, C.; de Dear, R.J.; Lamberts, R.; Bittencourt, L. Air movement acceptability limits and thermal comfort in Brazil's hot humid climate zone. Build. Environ. 2010, 45, 222-229. [CrossRef]

36. Tzikopoulos, A.F.; Karatza, M.C.; Paravantis, J.A. Modeling energy efficiency of bioclimatic buildings. Energy Build. 2005, 37, 529-544. [CrossRef]

37. Hua Ge, P. An infrared sphere method to measure mean radiant temperature. ASHRAE Trans. 2003, 19, 1F.

38. Aflaki, A.; Mahyuddin, N.; Baharum, M.R. The influence of single-sided ventilation towards the indoor thermal performance of high-rise residential building: A field study. Energy Build. 2016, 126, 146-158. [CrossRef]

39. Liping, W.; Hien, W.N. The impacts of ventilation strategies and facade on indoor thermal environment for naturally ventilated residential buildings in Singapore. Build. Environ. 2007, 42, 4006-4015. [CrossRef]

40. Parsons, K. Human Thermal Environments: The Effects of Hot, Moderate, and Cold Environments on Human Health, Comfort, and Performance; CRC Press: Boca Raton, FL, USA, 2014.

41. Sapian, A.R.; Madros, N.H.; Ahmad, M.H. Evaluation of thermal comfort performance in low cost flats: Case study of Sri Perak flats, Kuala Lumpur. Dev. Passiv. Sol. Des. Technol. Trop. Clim. 2001, 5, $23-33$.

42. Ashrae, A. Handbook of fundamentals. Am. Soc. Heat. Refrig. Air Cond. Eng. 2005.

43. Alfano, F.R.D.A.; Palella, B.I.; Riccio, G.; Toftum, J. Fifty years of Fanger's equation: Is there anything to discover yet? Int. J. Ind. Ergon. 2018, 66, 157-160. [CrossRef] 
44. Alfano, F.R.D.A.; Palella, B.I.; Riccio, G. Notes on the Calculation of the PMV index by means of Apps. Energy Procedia. 2016, 101, 249-256. [CrossRef]

45. ISO 7730. Ergonomics of the thermal environment-Analytical determination and interpretation of thermal comfort using calculation of the PMV and PPD indices and local thermal comfort. 2005.

46. Peeters, L.; De Dear, R.; Hensen, J.; D'haeseleer, W. Thermal comfort in residential buildings: Comfort values and scales for building energy simulation. Appl. Energy 2009, 86, 772-780. [CrossRef]

47. Olesen, B.W.; Parsons, K.C. Introduction to thermal comfort standards and to the proposed new version of EN ISO 7730. Energy Build. 2002, 34, 537-548. [CrossRef] 